\title{
Gene regulations and delivery vectors for treatment of cancer
}

\author{
Ming Chen ${ }^{1} \cdot$ Yu-Xin Ren ${ }^{1} \cdot$ Ying Xie $^{1} \cdot$ Wan-Liang Lu ${ }^{1}$
}

Received: 12 March 2020 / Accepted: 13 April 2020 / Published online: 19 April 2020

(c) The Author(s) 2020, corrected publication 2020

\begin{abstract}
Background Resistant residual cancer and cancer stem cells after comprehensive treatment often result in the recurrence of cancer. The refractory nature of cancer is an important scientific problem to be solved.

Area covered An emerging gene regulation strategy of cancer is involved in the cross field of chemistry, genomics, bioinformatics and pharmaceutical sciences, which could offer a possible solution to a curative strategy of cancer.

Expert opinion In this review, we dealt with the advances and applications of major gene regulation strategies, including DNA modification, gene editing and RNA regulations. Moreover, we also analyzed the representative transfection carriers for delivering the genetic material into cancer cells, including viral and non-viral vectors. Herein, we conclude that the gene regulation by a safe and high efficient transfection vector would be promising to provide a new treatment strategy for fully recovery of cancer disease.
\end{abstract}

Keywords DNA modification - Gene editing $\cdot$ RNA regulation $\cdot$ Gene delivery $\cdot$ Cancer

\section{Introduction}

Treatment of cancer covers a comprehensive strategy, mainly involving chemotherapy, surgical therapy, radiotherapy and immunotherapy, among which, chemotherapy plays a fundamental role in sweeping cancer cells during whole treatment procedure. However, resistant residual cancer and cancer stem cells after comprehensive treatment often result in the recurrence of cancer. The refractory nature of cancer remains as unsolved scientific and clinical issues. The achievements in human genome project inspire scientists to continuously investigate new strategies by biological approaches, in which gene regulation emerges promising prospect to get a curative solution to cancer therapy.

Since the human genome sequence and associated identification of approximately 30,000 genes were elucidated in the year 2001 (Lander et al. 2001; Venter et al. 2001), there have many new treatment methods been developed in the

Ming Chen and Yu-Xin Ren have contribute to this work equally.

Wan-Liang Lu

luwl@bjmu.edu.cn

1 State Key Laboratory of Natural and Biomimetic Drugs, Beijing Key Laboratory of Molecular Pharmaceutics and New Drug System, and School of Pharmaceutical Sciences, Peking University, Beijing 100191, China field of gene therapy. Based on genomic knowledge, gene regulation is used as a possible measure which is performed by putting corrective genetic material into cells to treat a variety of diseases, including cancers (Dunbar et al. 2018).

Gene regulation enables to correct the mutated genes of cancer cells, and promote the differentiation of cancer stem cells. Accordingly, gene regulation has the potentials to decrease the indefinite proliferation of mutated cells, to increase the sensitivity of anticancer drugs, and to block the invasion and metastasis, thus impeding the recurrence of cancer cells. Theoretically, gene regulation could offer a curative measure to the mutated cancer cells.

The gene regulation agents used cover small molecule and macromolecule gene drugs. All-trans-retinoic acid (ATRA) can be a typical small molecule gene drug that enables to promote the differentiation of low-differentiated cancer cells or cancer stem cells. A survey on 12-year clinical treatments reveals that the combining therapy of anthracycline chemotherapy with ATRA reaches remarkable outcomes in which 918 of 1025 patients whose acute promyelocytic leukemia (APL) get first complete remission (CR) (Montesinos et al. 2010). As for macromolecule ones, a number of gene drugs based on varied regulation strategies have been developed at laboratory stage or clinical trial stages. To better understand the current status, herein, we discuss the advances in the 
emerging gene regulation approaches, and delivery vectors for enhancing the treatment efficacy of cancer.

\section{DNA modification regulations}

\section{DNA methylation inhibitors}

DNA methylation is a way of chemical modification that alters genetic performance without changing DNA sequence. DNA methylation process is the covalent addition of the methyl group at the $5^{\prime}$ carbon of the cytosine ring under the action of a DNA methyltransferase (Fig. 1). The studies shows that DNA methylation can cause the changes in chromatin structure, DNA conformation, DNA stability, and DNA-protein interactions, thereby controlling gene expression (Galm et al. 2006; Auclair et al. 2012; Moore et al. 2013; Xie et al. 2019).
DNA methylation of tumor suppressor gene promoters is associated with the progression of cancer as it causes transcriptional silencing of tumor suppressor gene. Accordingly, DNA methylation inhibitors have been developed to induce re-expression of aberrantly silenced genes in cancer for inducing growth arrest, apoptosis or differentiation of cancer cells (Gros et al. 2012; Yu et al. 2019).

As methylation of cytosine-phosphoric acid-guanine $(\mathrm{CpG})$ islands rarely occurs in normal cells but exists in cancer cells (Park et al. 2011), DNA methylation provides a cancer-specific therapeutic target. Unlike the mutated gene, the DNA sequence and protein product of the methylated gene remain unchanged. Thus, normal gene function could be restored by application of inhibitors. The clinical results exhibit that the inhibitors are able to effectively treat hematologic malignancies in which certain genes are hypermethylated (Rush et al. 2002). For examples, azacitidine and its deoxy derivative decitabine are potent inhibitors of DNA methylation (Howell et al. 2010). The clinical

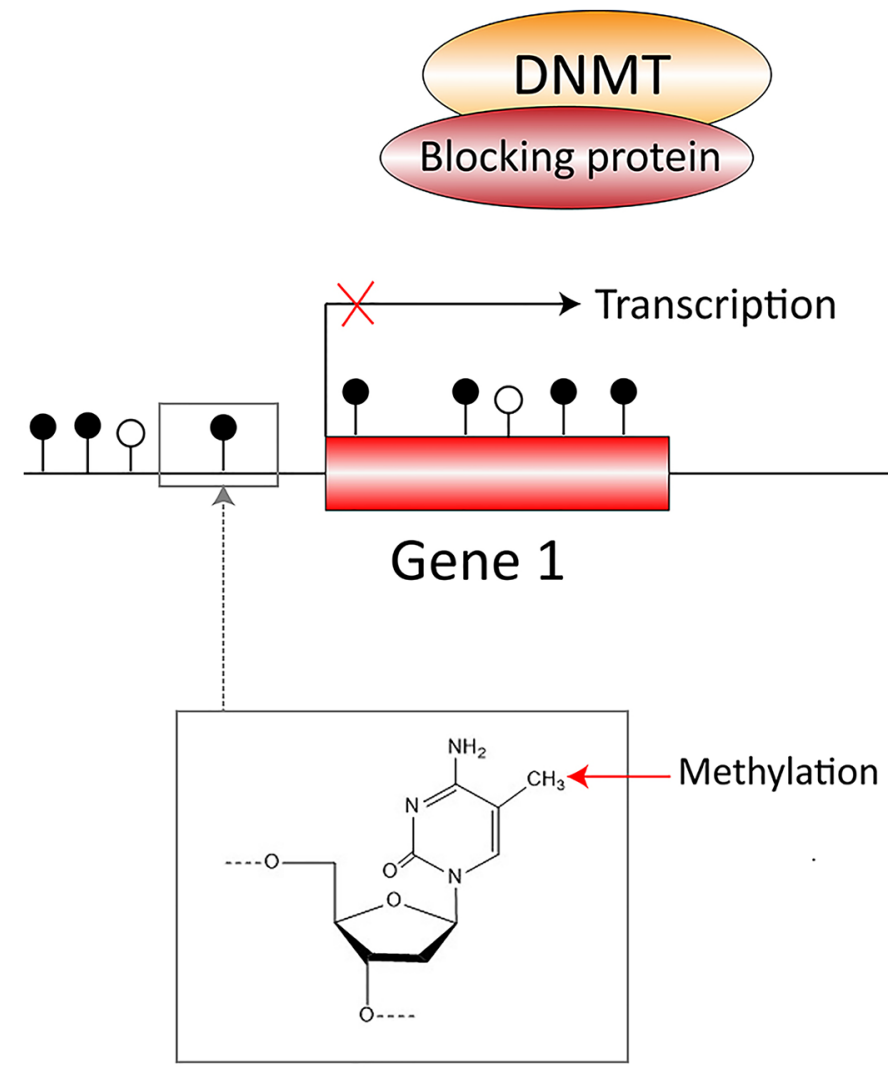

A. Methylated deoxycytidine
Fig. 1 DNA methylation resulting in cancer by disabling normal transcription of DNA. Notes Methylated DNA cannot bind to RNA polymerase leading to disabling the transcription of DNA due to the steric hindrance of methyl groups. In normal cells, DNA methyl transferase (DNMT) can remove methyl groups from genes and allow genes to be re-expressed. In cancer cells, however, DNMT is inhibited by methylated DNA, which facilitate the proliferation of cancer cells. A synthetic DNA methylation inhibitor enables to treat cancer by blocking this process 
study demonstrates that DNA methylation inhibitors can reverse many of the epigenetic changes in the target genes that play a role in myelodysplastic syndromes (MDS) and leukemia (Baba et al. 2017). Although these results indicate that the clinical activity of either azacitidine or decitabine is mediated through the reversal of silenced genes, the causal relationship and identification of key gene targets are still lacking (Derissen et al.2013; Hollenbach et al. 2010).

\section{Gene rearrangement and amplification}

Gene rearrangement refers to a phenomenon that a gene is moved away from a loci to a near loci in the promoter to initiate transcription. It occurs during the process of repairing DNA double-strand breaks, which leads to the conversional transfer of genes in the alleles or between alleles. DNA double-strand breaks often occur in the repeat unit near the $5^{\prime}$ end of the tandem repeat, forming two free overhanging single-stranded ends of the DNA molecule. However, in the process of repair, the two ends are not oscillated according to the position of the original paired base due to wobble or misalignment, resulting in two consequences: intra-gene and inter-gene rearrangements.

\section{Intra-gene rearrangement}

The result of intra-gene rearrangement is a phenomenon that the base at the very end of the mismatch chain is renatured first. Then the vacant bases are locally synthesized and repaired to form one or several insertions repeat units. As a single-strand insertion in the same-DNA molecule happens, the transfer of this gene is an intra-gene transformation. Intra-gene rearrangement can be repeated, and an inserted sequence is added every time it replicates. Therefore, the number of repeating units generally increases in the small satellite seat (Ledwith et al. 1995; Chang et al. 2019).

\section{Inter-gene rearrangement}

The result of intra-gene rearrangement is another common phenomenon that the free single-stranded end of a DNA is connected with the corresponding allele on the chromatid and then it renatures with the DNA of the other chromatid. The transfer undergoes between the genes of the different chromatids (Newman et al. 2014; Suurmeijer et al. 2019).

The phenomenon of gene amplification often happens as well. During this process, the copy number of a gene encoding a specific protein is selectively increased while other genes are not proportionally increased. Under natural conditions, gene amplification is achieved by excising repetitive sequences of gene from the chromosome and then performing extrachromosomal replication in the plasmid, or by generating an RNA transcript from the entire repeat of the ribosomal RNA to get an additional copy of the original DNA molecule. Many oncogenes in human cancer cells are highly expressed after extensive gene amplification, resulting in uncontrolled cell growth. The amplification rates of some oncogenes are highly correlated with the developmental rate of the cancer (Janjigian et al. 2011; Singhi et al. 2012).

Gene rearrangement and gene amplification are characteristic responses in the pathogenesis of cancer, resulting in excessive proliferation of tumor cells (Shaw et al. 2011; Seol et al. 2012; Jones et al. 2019). Gene rearrangement even makes it difficult to find targets for drug treatment. Therefore, a challengeable research task is to develop suitable agents to suppress the occurrence of gene rearrangement and amplification in cancer cells for treatment of cancer.

\section{Intercalative binding between DNA and drug}

Some of anticancer drugs take effect depending on intercalative binding to DNA. For example, daunorubicin is able to play anticancer activity by embedding in DNA in which the daunorubicin is embedded in the double helix of DNA via binding to $\mathrm{G}$ and $\mathrm{C}$ base pairs. Intercalation does not break the hydrogen bonds between base pairs. This intercalative binding eventually interferes with the replication and transcription of cancer cell DNA, achieving therapeutic effect.

\section{DNA cross-linking}

There are also plenty of chemical anticancer drugs that can directly crosslink DNA by chemical bonds. For instance, chlorambucil can mediate the bimolecular nucleophilic substitution (SN2) process to attack the N7-position of the guanine residue, which is an alkylation process and induces a cross-linking between chlorambucil and DNA. After the cross-linking, DNA's normal conformation is disrupted, thus hindering the replication and transcription of gene. Nonetheless, the efficacy of DNA cross-linking is still limited during treatment of cancer. To improve overall anticancer efficacy, scientists tried to enhance the efficacy of DNA cross-linking treatment by conjugated polymer. The conjugated polymer is a macromolecular material, which can enhance alkylation of chlorambucil. By conjugating chlorambucil with polymer, a polyfluorene derivative containing pendent alkylating chlorambucil moieties has been synthesized for DNA alkylation of cancer cells. By getting a tighter cross-linking with DNA than chlorambucil, the anticancer efficacy of the conjugated chlorambucil has been significantly enhanced in treatment of chronic lymphocytic leukemia, ovarian cancer and low-grade non-Hodgkin's lymphoma (Nie et al. 2013). 


\section{Gene editing regulations}

Gene editing refers to a technique that specifically changes the sequence of a target gene. To achieve the goal of gene editing, the exogenous cleavage complex is used to specifically recognize and cleave the gene sequence in the cell, and produce the cleavage end on the target gene sequence. Afterwards, the cleavage end is repaired by the DNA damage repair system inside the cell and rejoined to get purpose gene. Gene editing is now studying for the uses in the fields of cancer treatment, cytokine regulation, drug resistant gene knockout, etc. The edited cancer cells share the characteristics of high-differentiation level and low drug resistance, both of which are beneficial for eliminating cancer cells either by gene editing alone or by a combining gene therapy with chemotherapy.

\section{ZFN gene editing}

Zinc finger nuclease (ZFN) gene editing is a DNA endonuclease technique. ZFN consists of zinc finger protein (ZFP) and FokI endonuclease. The recognition domain of ZFN is composed of 3 to 4 Cys2-His2 zinc finger proteins, and each zinc finger protein recognizes a specific triplet base. Multiple zinc finger proteins are connected to form a zinc finger proteome, which recognizes a specific base sequence (9-12 bp) in the target gene. In the process of gene editing, a FokI endonuclease is connected with a zinc finger protein group to form a ZFN, which recognizes a specific site. When the recognition sites of two ZFNs are at a proper distance (6-8 bp), the interaction of two Fokls endonucleases produces the enzyme cutting function, so as to achieve the purpose of DNA fixed-point cutting (Gaj et al. 2013).

Zinc finger protein used in ZFN gene editing has a small molecular weight, which only needs about $2000 \mathrm{bp}$ in encoding a pair of ZFNs (Ul Ain et al. 2015). Such proteins can be easily introduced into the body for gene therapy by transfection of adeno-associated virus (AAV) vectors. In the field of scientific research and agriculture, the ZFN gene editing can be used not only to knock out or inactivate genes, but also to import target genes, activate or block genes or artificially modify gene sequences to meet a specific purpose. In the field of medical treatment, ZFN gene technique is used to transfect plasmids or stem cells that are further delivered into human body for achieving gene therapy. In addition, it can also be directly used to repair and replace harmful genes for achieving therapeutic purposes. ZFN gene editing has excellent specificity and efficiency so that it can minimize the risk of gene/genome errors.

However, the ZFN gene editing technique has an obvious shortcoming because it requires a large zinc finger protein library to target different gene sequences. In addition, when zinc finger proteins are linked together, they will interfere with each other, thus affecting DNA binding which leads to off-target of ZFN gene editing. Accordingly, a lot of screening work has to be performed in order to obtain an efficient and specific ZFN, and this work greatly hinders its popularization and application (Liu et al. 2018).

\section{TALEN gene editing}

Transcription activator-like effector nuclease (TALEN) is used for gene editing also by fusion of DNA binding protein and endonuclease Fok I. In 2007, scientists discovered that xanthomonas plantarum promoted its proliferation through transcription activator like effector (TALE) (Moscou et al. 2009).

TALE is produced by xanthomonas and secreted by its type III secretory system, and it is transported across the membrane of plant cells to act function in the nucleus of plant cells. TALE is able to target specific DNA sequence in promoter region to enhance the expression of plant gene. A nuclease TALEN can be assembled by connecting the TALE module with the cleavage domain of FokI nuclease. TALEN uses TALE residue to target the DNA sequence and uses Fokl to cut DNA, acting a gene editing role.

In 2009, scientists deciphered the base correspondence between the transcription activator-like effector (TALE) encoded by rice pathogens and DNA (Boch et al. 2009). Then, TALEN gene editing has been successfully applied in yeast (Joung et al. 2013) and subsequently applied to plants (Bogdanove et al. 2010), rats (Ferguson et al. 2013), zebrafish (Zu et al. 2013), and pigs (Tan et al. 2013).

In 2014, the decoding of all TALE components has been completed by using TALE protein assembly technology (ULtiMATE system) (Yang et al. 2013). Nowadays, many efforts have been made to develop biological products based on TALENs gene editing for treatment of severe illness, including cancer diseases.

\section{CRISPR/Cas gene editing}

CRISPR is a short DNA palindrome structure, which is named as "clustered regular interspaced short palindromic repeats" (CRISPR). CRISPR is previously found in bacteria that contains fragments of genes from viruses that once attacked the bacteria. It consists of a leader, several short and highly conserved repeats, and several spacers. Bacteria use CRISPR as an immune defense mechanism to ward off phages. In the absence of the virus, CRISPR immune defense system lies dormant and it can be induced when needed (Bak et al. 2018; Zhang et al. 2014). 
In the nearby flanking sequence of the CRISPR cluster, there exist polymorphic family genes that encode the proteins containing functional domains, showing the activities of nuclease, helicase, integrase, polymerase (Makarova et al. 2011a, b; Rath et al. 2015), etc. These genes can interact with nucleic acid, and play a role together with CRISPR region. Therefore, they are named CRISPR associated genes (Cas).

Cas genes discovered so far include Cas1-Cas10 and other types (Shalem et al. 2014). As a classical classification, CRISPR/Cas system has been divided into type I, type II, and type III according to the type and function of Cas proteins.

In the type I system, Cas1 and Cas2 integrate the cleaved PAM into the CRISPR sequence. Cas6 is responsible for processing pre-crRNA. Cas5, Cas7, and Cas8 identify the protospacer adjacent motif (PAM) on the invading DNA. Finally, Cas3 plays the cutting function.

In the type II system, Cas 1 and Cas 2 integrate the cleaved PAM into the CRISPR sequence. RNase III is responsible for processing the pre-crRNA, while Cas9 recognizes and cleaves the PAM.

In the type III system. Cas1 and Cas2 integrate the cleaved PAM into the CRISPR sequence. Cas6 is responsible for processing pre-crRNA. Cas5 and Cas7 recognize PAM on the invading DNA, and eventually Cas 10 plays a cleavage function.

Based on the classical classification and the mechanism of Cas protein interaction, the CRISPR/Cas system is now divided into two categories (Makarova et al. 2015; Jung et al. 2015): the first category contains type I and type III systems, which require multiple Cas proteins to form a complex to recognize and cleave PAM; the second category contains type II systems, which require only Cas9 for recognizing and cutting PAM. Because the recognition and cleavage process of Cas9 involves only one protein, CRISPR/Cas9 system has been mostly developed.

In the nature, when viral DNA invades bacteria, the Cas9 encoded protein, which contains a regeneration lobe (REC) and a nucleic acid lobe (NUC), can scan viral DNA to recognize PAM, and to excise the invaded viral DNA, because REC specifically recognizes DNA sequence while NUC has nuclease activity (Makarova et al. 2011a, b). The symbol of PAM is NGG bases sequence. This fragment is then integrated into the CRISPR sequence of bacteria. When viral DNA invades again, the CRISPR sequence is transcribed into precursor of CRISPR RNA (pre-crRNA), and the trans-activating crRNA (tracrRNA), which is transcribed at upstream of a CRISPR sequence, is complementary to pre-crRNA. Afterwards, Cas9 protein relies on REC to specifically recognize crRNA and bind to crRNA. RNase III excises the repeat of pre-crRNA, leaving only PAM and a few extra bases to generate crRNA.
Finally, crRNA, tracrRNA and Cas9 protein form a trisomy complex. This complex can unscrew the double helix of invaded viral DNA, and specifically recognize the PAM on the viral DNA, enabling crRNA to complement PAM. The complex cas9 protein has two endonuclease active domains: RuvC and HNH (Wu et al. 2013). The two subunits are respectively responsible for cutting a single strand of DNA. The HNH active site in Cas9 cut the complementary DNA chain with sgRNA, and the RuvC active site cut the non-complementary chain, and finally introduced the DNA double-strand break (DSB), resulting in the expression failure of the DNA invaded by the virus.

The gene editing technique is an engineering in which a single guide RNA (sgRNA) of about 20 bases is designed by fusing crRNA and tracrRNA artificially. To design sgRNA, the exon of the knockout gene needs to be determined firstly, and then a segment of sgRNA is obtained according to the principle of PAM sequence and base complementation in exons. The objective sequence of sgRNA is the PAM sequence containing NGG bases in the genome while the cutting site of Cas 9 is designed at 3 bp upstream of the PAM. Researchers usually use plasmids to transfer sgRNA and Cas9 into target cells, and the constructed plasmid sequence usually includes DNA sequence corresponding to sgRNA, Cas9 gene, marker gene (such as puromycin resistant gene) and green fluorescent protein gene. After the plasmid is transfected into the cell, the DNA sequences of Cas9 gene and sgRNA are transcribed by the enzyme of the target cell and translated into Cas9 protein, which further forms a complex with sgRNA and binds specifically to PAM of the target gene. Afterwards, Cas9 protein plays the role of nuclease activity and cuts the target gene. When double strands breaks occur, cells will repair their own DNA through two DNA repair pathways: non homologous endjoining (NHEJ) or homology directed repair (HDR) (Chen et al. 2013; Gratz et al. 2013). NHEJ is the direct reconnection of broken DNA. Due to the lack of template in this process, the deletion and mismatch of base will occur, resulting in the change of original gene and gene editing. HDR relies on another homologous chromosome as a template to repair the broken DNA (Fig. 2). The gene editing effect can be verified by Western blot, etc.

Nowadays, gene editing based on CRISPR/Cas9 systems have been applied in knock-out of cancer genes, such as proto oncogenes, and in the screening new targets for cancer treatment (Behan et al. 2019), and in treatment of cancer (Zou et al. 2018) and cancer stem cells (Mandal et al. 2014).

Compared with ZFN and TALEN gene editing techniques, CRISPR/Cas9 approach has demonstrated advantages in its simple process and economical aspect. However, lower transfection efficiency in cancer cells and possible base mismatch are still the major challenges for further developments. 


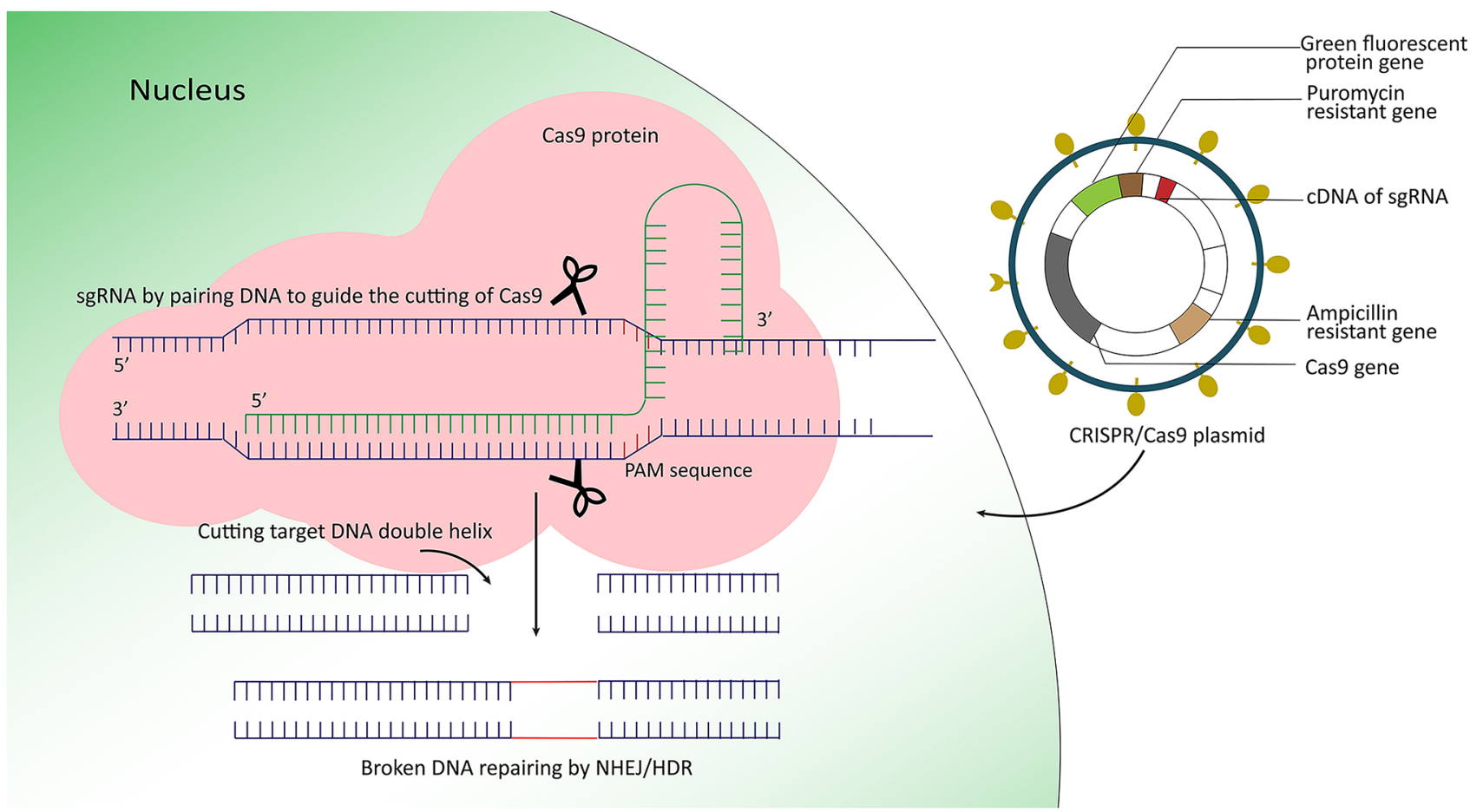

Fig. 2 Gene editing mechanism by artificial designed CRISPR/Cas9 system. Notes Artificially designed plasmid DNA is composed of green fluorescent protein gene, puromycin resistant gene, ampicillin resistant gene, cDNA of sgRNA and Cas9 gene; the plasmid carrying cDNA of sgRNA and Cas9 gene were transfected into the cell, usually by lentiviral vector or cationic liposomes for efficiently delivering the plasmid into the cellular nucleus (not shown); then plasmid DNAs enter nucleus and transcribe sgRNA and mRNA of Cas9; sgRNA stays in nucleus while mRNA of Cas9 goes outside the nucleus

\section{RNA regulations}

\section{Non-coding RNA and cancer treatment}

Ribonucleic acid (RNA) is a chain molecule of ribonucleotide, which is condensed by phosphodiester bonds. Each ribonucleotide consists of phosphate, ribose, and bases. There are four main types of RNA bases: adenine (A), guanine $(\mathrm{G})$, cytosine (C), and uracil (U). RNAs exist in biological cells, some viruses and viroids as the carriers of genetic information.

RNAs can be classified in a variety of ways, such as messenger RNA (mRNA), transfer RNA (tRNA), ribosomal RNA (rRNA), micro RNA (miRNA), small RNA, etc. RNAs are usually divided into coding RNA and non-coding RNA (ncRNA) as well, according to whether they encode proteins or not.

The coding RNA usually refers to mRNA, which is a single-stranded ribonucleic acid that is transcribed as a template from a strand of DNA and carries genetic information that guides protein synthesis. and translates Cas9 protein; Cas9 protein has nuclear localization sequence (NLS) so that it can enter nucleus through nuclear pore complex; Cas9 protein recognizes sgRNA and forms a binding complex; this complex finds the PAM sequence on DNA which is complementary to sgRNA and binds to it; sgRNA guides Cas9 protein to cut DNA double helix, resulting a double-chain notch; and finally cell repairs the broken DNA by non-homologous end-joining (NHEJ) or homology directed repair (HDR), which will remove the edited target gene

The ncRNA includes many types of RNAs, such as tRNA involved in transport of amino acids, rRNA involved in catalytic capacity, small nuclear RNA (snRNA) involved in mRNA splicing, small nucleolar RNA (snoRNA) involved in RNA modification, and so on.

The ncRNAs may act as either housekeeping for cell survival or regulatory role in transcription, translation and other processes (Carninci et al. 2007; Flippot et al. 2019; Griffiths 2007). The ncRNAs can also be divided into two categories according to their length: those larger than $200 \mathrm{nt}$ (nucleotides) are called long non-coding RNAs (lncRNAs) (Pauli et al. 2011), and those smaller than $200 \mathrm{nt}$ are called small non-coding RNAs (small ncRNAs). Among small ncRNAs, those less than 50 nt are called tiny ncRNAs, such as small interfering RNA (siRNA), microRNA (miRNA), Piwi-interacting RNA (piRNA), etc.

It has been found that the abnormal expressions of ncRNAs are closely related to the occurrence and development of cancers, including digestive system neoplasm ( $\mathrm{Su}$ et al. 2017), respiratory system tumors (Zhang et al. 2015), urogenital system tumors (Baker et al. 2018), lymphatic 
hematopoietic system tumors (Kurita et al. 2016), etc. These findings open a new research field in artificial RNA regulations for diagnosis and treatment of cancers.

\section{IncRNA regulations}

According to the data from the ENCyclopedia of DNA Elements (ENCODE) Project Alliance in 2012, 9640 of lncRNAs loci have been identified in human genome, and are waiting for functional verification (ENCODE Project Consortium 2012; Derrien et al. 2012). The scientists reveal that IncRNAs are implicated in serial steps of cancer development. IncRNA can interact with DNA, RNA protein molecule or/and their combinations and play vital role in chromatin organization, transcriptional and post-transcriptional regulation (Mercer et al. 2009). lncRNA has become an important regulatory target of almost all aspects of biology (Tsai et al. 2011). The irregular expressions of lncRNA are closely associated with the development of cancer as well, and therefore, IncRNAs are emerging as the promising treatment targets of cancers, despite that the function and structure for a number of lncRNAs remains unknown.

Each IncRNA has a complicated secondary and tertiary structure, while the complicated structure confers the ability of lncRNA to bind protein, RNA and/or DNA partners, thereby providing multiple regulatory capabilities. Over the past few years, studies have revealed many regulatory roles of lncRNAs. For example, lncRNAs can interact with PRC complex (polycomb repressive complex), which play roles in tumor progression and development by blocking differentiation and promoting stem cell self-renewal (Yang et al. 2014; Richly et al. 2011). Besides, IncRNAs are involved in regulation of mRNA biogenesis of the cells (Rinn et al. 2012; Hung and Chang 2010; Dandan et al. 2019). Action modes of IncRNA can be roughly divided into four categories: signal, guide, decoy, and scaffold (Pandey et al. 2008), as the following descriptions.

The signal mode refers to the action way that lncRNA takes part in the signal transmission of a specific pathway as a signal molecule, thereby regulating transcription of downstream genes. For examples, lncRNA p21 acts as a signal molecule of p53 signaling pathway by interacting with heterogeneous nuclear ribonucleoprotein-k (hnrnp-k) to inhibit the expression of downstream genes in the process of p53-mediated apoptosis (Plath et al. 2002; Kino et al. 2010).

The guide mode is a process that IncRNA can specifically bind with a protein (usually a transcription factor), and then localize the protein complex to a specific DNA sequence for regulating the transcription of genes. For example, lncRNA HOTAIR specifically binds with downstream HOXD transcription factor to form a protein complex, which further recruits polycomb regressive complexes (PRC2) and lysine specific demethylase 1 (LSD1) by non-covalent manner to regulate methylation of histone. Accordingly, trimethylation happens in two lysine positions of histone H3 (position 27 and position 4, respectively). In normal physiological process, trimethylation degree of histone $\mathrm{H} 3$ is in a suitable range. Once HOTAIR is over-transcribed in a pathological situation, and histones $\mathrm{H} 3$ will be overly methylated, causing chromatin reprogramming and chromosome blocking. This pathological situation usually happens in cancer cells. A gene regulation study demonstrates that down-regulation of HOTAIR significantly reduces the invasiveness and proliferation of breast cancer cells (Dandan et al. 2019).

The decoy mode is a transcriptional regulation way that lncRNA plays effect as a bait by combining with transcription factors, chromosomal folding proteins or other RNAs (such as miRNA) to block their functions. For example, lncRNA PCAT-1 is able to block the function of miRNA34 by a decoy mode via binding with miRNA-34 (Tripathi et al. 2010). In prostate cancer cells, PCAT-1 is overly transcribed and binds with miRNA-34, and such a decoy binding up-regulates the expression of oncogene myc-3, resulting in the proliferation and metastasis of prostate cancer cells. The investigations reveal that down-regulation of lncRNA PCAT-1 significantly decreases proliferation and migration of prostate cancer cells (Prensner et al. 2014).

The scaffold mode is a process that IncRNA binds to multiple effector molecules simultaneously, providing a platform for interactive regulation. For example, HOTAIR not only plays a role by the guide mode, but also by the scaffold mode. Its $5^{\prime}$ end binds to the $P R C 2$ complex, while its $3^{\prime}$ end simultaneously with another complex LSDI (Rinn et al. 2007; Tsai et al. 2010). In healthy human cells, Hotair acts as a scaffold to simultaneously bind with both the $P R C 2$ complex and the $L S D 1$ complex, regulating the methylation of DNA (Wang and Chang 2011; Zhu et al. 2013).

\section{RNA interference}

RNA interference (RNAi) is a natural phenomenon that is induced by double-stranded RNA to efficiently and specifically degrade homologous mRNA in eukaryotes (Fire et al. 1998). Eukaryotes use small interfering RNA (siRNA) to defend against the invasion of exogenous viral RNA (Fig. 3).

When a virus invades into a eukaryotic cell, the long chain of viral double stranded RNA (dsRNA) is cut into a small dsRNA (20-25 nt dsRNA, i.e., siRNA) by an endogenous Dicer protein (a ribonuclease RNase III-like enzyme) of the cells. The double strand of siRNA is further dissociated by helicase into two single strands: a sense strand, and an antisense strand. The antisense strand of dissociated siRNA combines with Dicer and Ago (Argonaute) proteins to constitute a RNA-induced silencing complex (RISC). RISC specifically binds to the homologous region of an objective mRNA, acts the function of 




Fig. 3 Mechanism of RNA interference. Notes 1-Eukaryotes use natural RNA interference (RNAi) mechanism to defend the invading of exogenous virus. When virus invades a eukaryotic organism, the long dsRNA of virus enters the cell; then the long dsRNA is cut by Dicer under the involvement of ATPase into a short chain of siRNA; the short double strand of siRNA is unchained by helicase; the unchained single chain constitutes a RISC complex with Dicer and Ago (Argonaute) proteins; RISC complex binds to the mRNA which is complementary to siRNA and degrades the target mRNA, thereby defending the invading of exogenous virus. 2-RNAi technique

nuclease, and cuts the mRNA at the binding site. The cutting site is the complementary and binding ends of the antisense chain in siRNA. The cut mRNA then degrades, triggering a host cell response to these mRNAs. During this process, siRNA can not only guide RISC to cut homologous single-stranded mRNA, but also be used as a primer to bind to the target RNA, and synthesize more new dsRNAs under the involvement of RNA-dependent RNA polymerase (RdRP). The newly synthesized dsRNA is then cut by Dicer to produce more secondary siRNA, eventually resulting in a cascade reaction till complete degradation of the target mRNA (Lima et al. 2012). Therefore, siRNA blocks the invaded viral gene expression by degrading its mRNA.

Based on the principle of siRNA, the researchers design an artificial siRNA to silence the target gene. The artificial siRNA (usually 20-25nt short double-stranded RNA) is designed for interfering the transcription of a target mRNA, which is responsible for expression of disease gene, such as cancer gene. When the artificial siRNA is delivered into cell cytoplasm by suitable vectors, such as retroviruses or cationic liposomes, the delivered siRNA eventually degrade diseaserelated mRNA, thereby acting a target gene silencing effect is designed by mimicking natural RNAi and an artificial designed siRNA is used to silence target gene of cancer disease. The double strand of siRNA is artificially designed and transfected into cancer cell, usually delivering by a viral vector or non-viral vector; the short chain of siRNA is no need to cut by Dicer, but only under the involvement of ATPase, siRNA is unchained by helicase; the unchained single chain constitutes a RISC complex with Dicer and Ago (Argonaute) proteins; RISC complex binds to the mRNA which is complementary to siRNA and degrades the target mRNA, thereby silencing the expression of target gene in cancer cell

by post-transcriptional regulation (Fig. 4) (Shen et al. 2012; Ozpolat et al. 2014).

siRNA technique has unique advantages, as follows: (i) high efficiency: after the antisense strand of siRNA recognizes and binds to the target mRNA, eventually resulting in a cascade reaction till complete degradation of the target mRNA, as discussed above; (ii) high specificity: RNAi only degrades the specific mRNA of a single endogenous gene corresponding to its sequence, showing less side effect; (iii) long-distance transmission: the inhibitor function of siRNA can cross a cell boundary, transmit and maintain signals over long distances between different cells and even spread throughout the organism. Therefore, siRNA technique has been a remarkable research hotpot. Up to date, siRNA technique has successfully been used in clinical trials for treatment of pancreatic cancer (Golan et al. 2015), leukemia (Schultheis et al. 2014), etc.

\section{Delivery vectors for gene regulations}

To meet a purpose of gene therapy, a number of carriers or vectors have been developed for safely and efficiently delivering the genetic material into the cells, mainly consisting 
Fig. 4 Mechanism of non-viral vectors for carrying siRNA. Notes 1 -The cationic liposome is liposome modified by a positively charged lipid material; these cationic groups on cationic liposomes are electrostatically attracted to the negatively charged siRNA; and siRNA is carried by cationic liposomes to form a delivery system for transfecting cancer cells. 2The polymeric nanoparticles could be prepared by cationic polymers, mixed electroneutral polymers with a specific substance (such as Zn complex); accordingly, polymeric nanoparticles bind to siRNA or coordination bonds to form a delivery system. siRNA is carried by cationic nanoparticles by electrostatic attraction and hydrogen bonds, or by coordination bonds with $\mathrm{Zn}$-containing nanoparticle, to form a delivery system for transfecting cancer cells

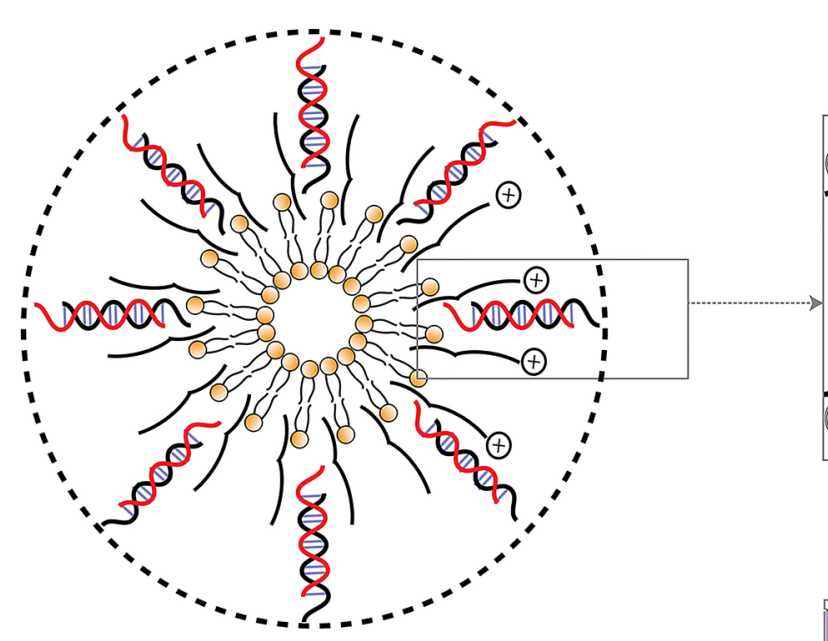

1. A cationic liposome carrying siRNA

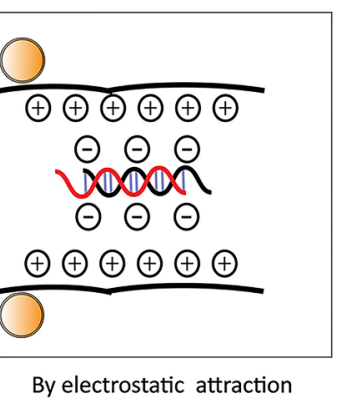

By electrostatic attraction

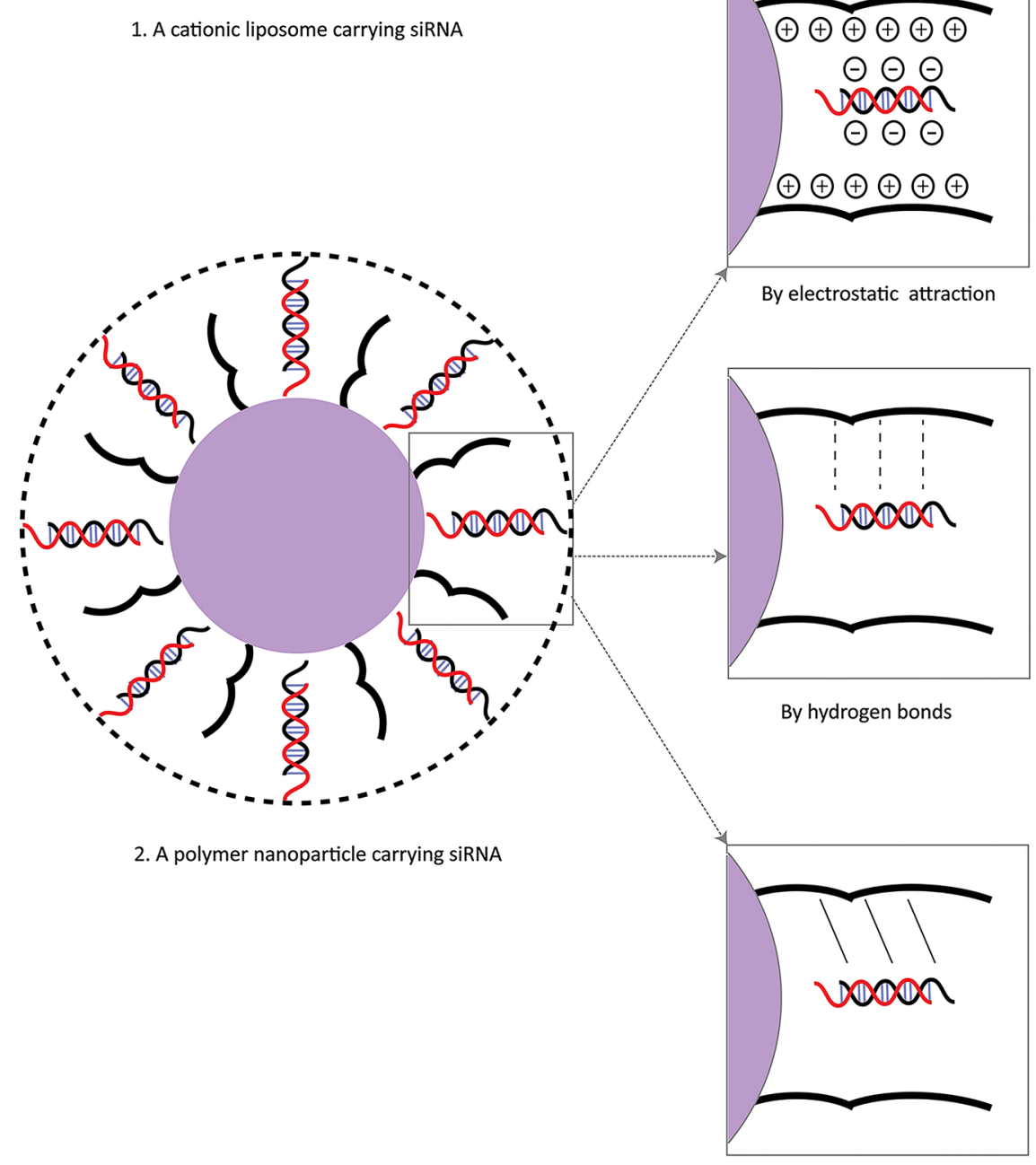

By coordination bonds

of viral vectors and non-viral vectors. Viral vectors have the ability to deliver genetic material into cancer cells by encapsulation of viruses, including retrovirus, lentivirus, adenovirus, etc. (Kenneth et al. 2018). Viral vectors share the properties of high transfection efficiency but are plagued by safety concerns such as immunogenicity.
Therefore, non-viral vectors are extensively engineered to deliver genetic material into cancer cells, including cationic liposomes, polymeric nanoparticles, dendrimers, etc. Nonviral vectors are able to mediate gene transfer in cells with a safer property, and accordingly, are widely being used in the gene therapy of cancers. 


\section{Retroviral vectors}

Retroviruses are a class of RNA viruses, which need to first convert RNA into cDNA under the action of reverse transcriptase, and then to amplify under the action of DNA replication, transcription, translation and other proteases. In 1970s, scientists discovered Moloney murine leukemia retrovirus (Schlom et al. 1970), which can use RNA as a template according to the principle of base complementarity. Retroviruses have three core genes: gag, encoding the core protein of the virus; pol, encoding the reverse transcriptase; and $e n v$, enveloping glycoprotein to generate the virus. Retroviruses can be efficiently integrated into the host's genome (Morita et al. 2000; Elsner and Bohne 2017).

When constructing a retroviral vector, a recombinant retroviral vector containing multiple cloning sites is required first. The gag, pol, and env structural genes need to be removed, while the packaging signals and related sequences need to be retained. To do these, engineered packaging cells that can provide retroviral proteins, such as the HEK293 cells, where the packaging signals are integrated in the packaging cell line chromosome.

The safety concern for retroviral vectors used in gene delivery is that their accidental random integration can cause harmful effects, such as mutagenesis of insertion (Bushman 2020), activation of proto-oncogenes, or inactivation of tumor suppressor genes. In addition, retroviruses can only selectively infect dividing cells, and once they produce replicable viruses, their toxicity become dangerous. Nonetheless, retroviruses have the advantages that they can integrate into the host's genome, and they can make foreign gene expression durable and stable. Accordingly, more and more retroviral vectors have been developed for multipurpose genetic investigations (Chen et al. 2020) and gene therapy of cancers, including leukemia (Müller et al. 2020; Quintarelli et al. 2019) ovarian (Qi and Mi 2016; Wang et al. 2015), brain (Tamura et al. 2019; Chen et al. 2020), lung cancers (Grzeskowiak et al. 2018), etc.

\section{Lentiviral vectors}

Lentivirus is a genus of the retrovirus family, which consists of human immunodeficiency virus (HIV), simian immunodeficiency virus (Sharp et al. 2005), equine infectious anemia virus, etc. (Tigre et al. 2017). Lentivirus can infect human cells and vertebrate cells, and the primary infected cells are mainly lymphocytes and macrophages. Lentivirus infection is characterized by the fact that most infected individuals experience an incubation period of several years before typical clinical symptoms, followed by a slow onset of disease, hence these pathogens are called slow viruses (Milone and Doherty 2018).
Lentiviral vector commonly used for gene therapy is derived from human immunodeficiency virus-1 (HIV-1). Its vector system and provirus structure are basically the same as that of retrovirus, while it can integrate not only with the DNA of dividing cells but also non-dividing cells, enabling to efficiently transfect cells and stably express the genes in both dividing and non-dividing cells (Benskey and Manfredsson 2016).

Lentivirus packaging system generally consists of lentiviral expression vector and lentiviral packaging vector (Dull et al. 1998). Lentivirus-packed plasmids, on the other hand, provide all the helper proteins needed for transcription and packaging RNA into recombinant pseudoviral vectors. In order to produce high-titer virus particles, the cells need to be co-transfected with expression vector and packaging plasmid, and the virus is packaged in the cells. The packaged pseudovirus particles are secreted into the extracellular medium, and centrifuged to obtain supernatant, which can be directly used for the infection of host cells (Benskey and Manfredsson 2016).

For the safety of purpose, lentiviral vectors have been made a series of modifications (Lee and Cobrinik 2020; Sakuma et al. 2012; Nobles et al. 2020), and widely used as the gene delivery carriers in treatments of breast cancer (Krishnamachary et al. 2017), lung cancer (Cui et al. 2020), gastric cancer (Park et al. 2020), leukemia (Müller et al. 2020), etc.

\section{Adenoviral vectors}

Adenovirus (AdV) is a DNA virus that typically causes mild infections involving the respiratory tract, gastrointestinal tract or conjunctiva. It belongs to a double-stranded DNA virus without envelope, and can be classified into 7 species (A to $\mathrm{G}$ ) with 57 serotypes based on their hemagglutination properties, oncogenic potential, genotyping and phylogenetic analyses (Chen and Lee 2014).

Adenovirus was one of the most studied and published viral vector in gene therapy clinical trials as it has a robust transduction profile, particularly in the liver. However, adenovirus was also accompanied by strong immune responses. The early clinical trials for gene therapy using adenovirus did not have many successes because of the nonspecific binding of adenovirus to blood components (Hendrickx et al. 2014), and antibodies against common adenovirus 5 serotypes in adults (Nwanegbo et al. 2004), and one trial caused a tragic fatality (Raper et al. 2003).

To reduce the immunogenicity of adenoviral vectors, the attenuation of the viral toxicity can be achieved by removing different components, including complete removal of all genetic information to be a 'gutless' vector (Capasso et al. 2014). Adenoviruses have two main groups of genes named early (E) and late (L) genes. E genes are responsible for virus 
DNA replication and for controlling the host cell metabolism, while L genes encode for all the structural proteins necessary for the capsid (Thomas and Mathews 1980). First generation adenoviral vectors delete E1 and/or E3 genes, and, for this reason, they are unable to replicate inside 'normal' cells. Second generation adenoviral vectors combine deletions of E1 and E3 with deletions in E2 or E4 regions (Silva et al. 2010). The reduced number of viral genes results in a decreased background production of viral proteins. Moreover, the most advanced adenoviral vectors are devoid of all viral genes, except for the two inverted terminal repeats (ITRs) and the packaging signal (psi) (Brunetti and $\mathrm{Ng}$ 2011; Toietta et al. 2002). The enhanced safety profile of the advanced adenoviral vectors makes them the safest adenoviral vectors available nowadays for gene therapy.

Besides, multiple modifications have been made on adenoviral vectors, such as chemical and non-chemical modifications by PEGylation (Hiwasa et al. 2012), and polymer engineering (Zeng et al. 2012). A number of clinical trials using adenoviral vector to target a number of different cancers, such as prostate, ovarian, bladder, lung, colorectal and refractory solid tumors (Hemminki et al. 2015; Freytag et al. 2014; Kim et al. 2013; Burke et al. 2012; Pesonen et al. 2012; Ji et al. 1999; Archid et al. 2020).

\section{Cationic liposomes}

Liposome is an artificially designed lipid bilayer structure of a closed vesicle, which is also named artificial cell. The liposomes have widely used as drug carriers for delivering gene or chemical drugs because of their unique capabilities of carrying drugs and targeting specific tissues or cells by modifying liposome membrane. Cationic liposomes are the modified liposomes with positively charged membrane material, such as dimethylaminoethanecarbamoyl cholesterol (DC-cholesterol), as described below.

The major components of liposomes consists of phospholipids and cholesterol. Phospholipids can be available from both natural and synthetic sources. Naturally derived phosphatidylcholine is a mixture extracted from either egg yolk or soybean, and each has a different length and different saturation of the fatty chain. Synthetic phosphatidylcholine derivatives include dipalmitoyl phosphatidyl choline (DPPC), distearoylphosphatidyl choline (DSPC), polyethyleneglycol distearoylphosphatidylethanolamine (PEG-DSPE), etc. As a primary membrane ingredient of natural cells, cholesterol is another important component of liposomes, as cholesterol tends to weaken the bonds between lipids and protein complexes in the membrane, acting as a 'buffer' to regulate the 'fluidity' of the membrane structure. These materials are electroneutral, and often are used to prepare liposomes for carrying chemical anticancer drugs, such as doxorubicin liposomes (Pujade et al. 2010).
Positively charged lipids are often used to prepare gene transfected liposomes. Positively charged lipids used in the preparation of liposomes are all synthetic products. Currently, positively charged lipids commonly used include stearamide, DOTMA ( $N$-[1-(2,3-dioleyloxy) propyl]$N, N, N$-trimethylammonium chloride) (Gaucheron et al. 2002), DOSPA ( $N$-[1-(2,3-dioleyloxy) propyl]- $N$-(2(sperminecarboxamido) ethyl)- $N, N$-dimethylammonium trifluoroacetate), DC-cholesterol, etc.

With the successful development of efficient cellular gene transfection method using cationic liposomes formed by DOTMA and DOPE (dioleoylphosphatidylethanolamine) (Gaucheron et al. 2001; Kim et al. 2015), various cationic lipids have been extensively studied. As amphiphilic cationic lipid is composed of a cationic head and a hydrophobic tail, the head group of a positively charged positive lipid interacts with the phosphate group of a negatively charged nucleic acid to form liposome complex (Fig. 4). This complex can be endocytosed or fused to the cell membrane by chargeto-charge interactions. In the endosome environment, the conformational changes of the neutral lipids in the cationic liposomes cause the complex to be released into the cytoplasm, thereby preventing nucleic acid drugs from being destroyed by the lysosome.

Cationic liposomes feature good physical stability, low toxicity, simple preparation, and low cost, while their transfection efficiency are barely satisfactory in the gene therapy, particularly in the intractable human cancer cells.

Nevertheless, various new cationic liposomes have been developed for gene therapy of cancers (Chien et al. 2005; Zhi et al. 2018; Zhen and Li. 2019), such as carboxybetaine-modified cationic liposomes carrying miRNA let$7 a$ for treatment of lung cancer (Lee et al. 2013), cationic liposome-conjugated RNAi molecule targeting thymidylate synthase for treatment of ovarian cancer (lizuka et al. 2018), cationic liposomes carrying Mcl-1 siRNA for treatment of pancreatic cancer (Wang et al. 2019), etc.(Table 1).

To optimize the transfection efficiency and to decrease the toxicity of cationic liposomes, a number of lipids-based vesicles have been developed. For example, a formulation of liposome containing DNA and a pH-sensitive calcium phosphate $(\mathrm{CaP})$ core is developed as an efficient delivery vector. In this unique liposome vector, $\mathrm{CaP}$ can rapidly dissolve at the acidic endosome $\mathrm{pH}$, releasing its cargo into the cytoplasm (Li et al. 2010), so that the targeted liposome vector releases more siRNA cargo to the cytoplasm, leading to a significant ( $\sim 40$-fold in vitro and $\sim 4$-fold in vivo) improvement in siRNA delivery (Yang et al. 2012).

\section{Polymeric nanoparticles}

Polymeric nanoparticles (PNPs) are defined as granular dispersions or solid particles with a size, usually in the 
Table 1 An example list of viral and non-viral vectors for gene delivery in treatment of cancers

\begin{tabular}{|c|c|c|c|c|}
\hline Vectors & Gene drug & Target & Disease & References \\
\hline \multirow[t]{4}{*}{ Retrovirus } & $\begin{array}{l}\text { Yeast cytosine deaminase } \\
(\mathrm{CD}) \text { and E. coli nitro } \\
\text { reductase (NTR) prodrug } \\
\text { activator gene }\end{array}$ & $\begin{array}{l}\text { 5-FC (5-fluorocytosine) and } \\
\text { CB1954 }\end{array}$ & Brain cancer & Chen et al. (2020) \\
\hline & LAH4-A4 & CD19 & Leukemia & Quintarelli et al. (2019) \\
\hline & $\begin{array}{l}\text { Antisense oligonucleotide } \\
\text { (ASODN) }\end{array}$ & Telomerase & Ovarian & Qi and Mi (2016) \\
\hline & $\begin{array}{l}\text { DNA-barcoded cDNAs with } \\
\text { Cre recombinase }\end{array}$ & c-MYC pathway & Lung cancer & Grzeskowiak et al. (2018) \\
\hline \multirow[t]{4}{*}{ Lentivirus } & CART19 & CD19 & Leukemia & Nobles et al. (2020) \\
\hline & shRNA & Choline kinase (Chk) & Breast cancer & Krishnamachary et al. (2007) \\
\hline & shRNA & $\begin{array}{l}\text { Vascular endothelial growth } \\
\text { factor A (VEGF) }\end{array}$ & Gastric cancer & Park et al. (2020) \\
\hline & SOX2 & hsa-miRNA-340-5p & Small-cell lung cancer & Cui et al. (2020) \\
\hline \multirow[t]{4}{*}{ Adenovirus } & CG0070 gene & RB pathway & Bladder cancer & Burke et al. (2012) \\
\hline & GM-CSF gene & p16/Rb pathway & Refractory solid tumor & Pesonen et al. (2012) \\
\hline & FHIT gene cDNA & FHIT gene & Lung cancer & Ji et al. (1999) \\
\hline & miRNA-143 & KRAS gene & Colorectal cancer & Archid et al. (2020) \\
\hline \multirow[t]{4}{*}{ Cationic liposomes } & shRNA & Against thymidylate synthase & Ovarian cancer & Iizuka et al. (2018) \\
\hline & c-raf siRNA & c-raf gene & Breast cancer & Chien et al. (2005) \\
\hline & let-7a miRNA & $\begin{array}{l}\text { EphA2 (ephrin type-A recep- } \\
\text { tor 2) }\end{array}$ & Lung & Lee et al. (2013) \\
\hline & Mcl-1 SiRNA & Mcl-1 gene & Pancreatic cancer & Wang et al. (2019) \\
\hline \multirow[t]{4}{*}{ Polymeric nanoparticles } & FAK siRNA & CD44 & Ovrian cancer & Byeon et al. (2018) \\
\hline & siRNA & CD44, CD6 & Cancer & Liu et al. (2012) \\
\hline & $\begin{array}{l}\text { Anti-EGFR monoclonal anti- } \\
\text { body h-R3 }\end{array}$ & EGFR & Breast cancer & Lim et al. (2017) \\
\hline & miRNA145 & Oct4/Sox $2 /$ Fascin 1 & Lung adenocarcinoma & Chiou et al. (2012) \\
\hline
\end{tabular}

range of 25-100 $\mathrm{nm}$. PNPs are produced by biocompatible and biodegradable polymers where the chemical drug is dissolved, encapsulated or attached to a nanoparticle matrix (Soppimath et al. 2001; Mohanraj and Chen 2007; Karlsson et al. 2018). Depending on the preparation method, nanospheres or nanocapsules can be obtained. Nanocapsule is system where the drug is confined in a cavity surrounded by a unique polymer film, while nanosphere is matrix system where the drug is physically and uniformly dispersed (Sant 2012). As for gene drugs, their encapsulation can be achieved by electrostatic attraction, hydrogen bonds and/or coordination bonds (Fig. 4).

PNPs are a class of the most common non-viral vectors for delivering gene drugs because they can be modified by various chemical approaches for achieving beneficial transfection purposes of a high permeability and long retention effect of tumor tissue (Owens and Peppas 2006; Couvreur and Vauthier 2006; Pack et al. 2005), high protective effect in blood circulation (Matsumura and Maeda 1986; Duncan 2003) and in cellular lysosomes for avoiding degradation of the carried gene drugs.
Polyethyleneimine (PEI), poly lactic-coglycolic acid (PLGA), and Zn-hyaluronic acid complex are used as the materials of polymeric nanoparticles by incorporating gene drugs in different ways.

Polyethyleneimine is a type of polymeric material that has been used as gene vector in recent years. It has shown excellent transfection ability in the gene therapy because its cationic structure is very suitable for packaging nucleic acids. Polyethyleneimine has a protonated amino nitrogen atom for every 3 monomers, hence being called a 'proton sponge'. Because of the protonated amino nitrogen atom, PEI can combine with siRNA by electrostatic attraction (Neuberg and Kichler 2014). Such a property makes PEI effectively protect nucleic acids from degradation of siRNA in acidic environment during endocytosis. To enhance the targeting to a specific cancer tissue, PEI can also be modified by a target molecule with chemical linkage or physical assembly approach. For instance, pullulan, a polysaccharide polymer consisting of maltotriose units, is introduced into polyethylenimine (PEI) to carry siRNA for targeting liver cancer, where, PEI encapsulates siRNA by electrostatic attraction 
while the modified pullulan plays two functions, i.e., specific targeting liver cancer, and weakening the surface positive charges of PEI nanoparticles. Accordingly, pullulan-PEI siRNA nanoparticles not only increase the anticancer effect but also reduce the cytotoxicity to normal cells from the positively charged PEI (Kang et al. 2010).

PLGA is a biodegradable high-molecular polymer, which is formed by the condensation of two kinds of monomers, lactic acid (LA) and glycolic acid (GA). PLGA is approved by the US FDA and widely used in clinical medicine. PLGA features good biocompatibility, biodegradability, simple synthesis, high stability, large mechanical strength, adjustable degradation rate, and good plasticity. PLGA combines with siRNA through hydrogen bonds and hydrophobic interaction to form a polymeric siRNA nanoparticle complex (Hazekawa et al. 2019). Similarly, PLGA can also be modified by a targeting molecule for achieving a more specific accumulation in cancer cells. For example, CD44-modified PLGA were used to carry FAK siRNA to treat ovarian cancer (Byeon et al. 2018).

$\mathrm{Zn}$-hyaluronic acid complex is a kind of polymeric nanoparticle assembly by combining Zn-dipicolylamine with hyaluronic acid, where, zinc can tightly bind with siRNA by coordination bonds. Because of the hydrophobic property, Zn-hyaluronic acid complex enables to simultaneously carry siRNA and hydrophobic anticancer drug, thereby achieving a combining anticancer therapy (Liu et al. 2012).

Actually, polymeric nanoparticles have become a very active research field, and numerous polymeric nanoparticles are developed, in particular, for the gene therapy of cancers. Among these, positively charged polyamidoamine dendrimer (PAMAM) also exhibits a promising suitability that it can bind with the negatively charged pDNA or siRNA molecule for treatment of breast cancer, (Li et al. 2015, 2018) cervical cancer (Lim et al. 2017) and lung cancer (Chiou et al. 2012).

\section{Conclusion}

Gene regulations enable to stop the expression of mutated genes by direct blocking, translational or post-translational interference, and to enhance the sensitivity of chemotherapy by inducing the differentiation of immature malignant cells (oncogenic stem or progenitor cells), demonstrating remarkable efficacy in eradicating the refractory cancer cells. Gene regulations can be achieved by DNA modifications, gene editing, and RNA interference. Among which, RNA interference technique has made a successful advance in treatment of human disease as a globally first commercial siRNA product to treat amyloidosis neuropathy (patisiran), while more siRNA drugs are still in evaluation stages in laboratory or clinical trials for treatment of cancers. Accordingly, number of viral and non-viral vectors have been developed for delivery the genetic materials into the target cancer cells, such as the outstanding advances in retroviral vectors, lentiviral vectors, adenoviral vectors, cationic liposomes, and polymeric nanoparticles. Each of them enables to deliver gene drug in its unique mechanism but shares a common result, namely, highly effective treatment of cancer. To achieve this objective, there have still bottlenecks of gene regulation strategy in two aspects, including a remarkable gene regulation target, and a safe and high efficient transfection vector. It could be prospect that the breakthrough in fully recovery of severe cancer disease would be made in the field of gene regulation, with the increase in understanding of functional genomes.

\section{Compliance with ethical standards}

Conflict of interest The authors declare that they have no conflict of interest.

Statement of human and animal rights This article does not contain any studies with human and animal subjects performed by any of the authors.

Open Access This article is licensed under a Creative Commons Attribution 4.0 International License, which permits use, sharing, adaptation, distribution and reproduction in any medium or format, as long as you give appropriate credit to the original author(s) and the source, provide a link to the Creative Commons licence, and indicate if changes were made. The images or other third party material in this article are included in the article's Creative Commons licence, unless indicated otherwise in a credit line to the material. If material is not included in the article's Creative Commons licence and your intended use is not permitted by statutory regulation or exceeds the permitted use, you will need to obtain permission directly from the copyright holder. To view a copy of this licence, visit http://creativecommons.org/licenses/by/4.0/.

\section{References}

Archid R, Zieker D, Weinreich FJ, Hönes F, Königsrainer A, Quintanilla MA, Reymon MA, Solass W (2020) shRNA-mediated inhibition of PhosphoGlycerate Kinase 1 (PGK1) enhances cytotoxicity of intraperitoneal chemotherapy in peritoneal metastasis of gastric origin. Eur J Surg Oncol 46:613-619

Auclair G, Weber M (2012) Mechanisms of DNA methylation and demethylation in mammals. Biochimie 94(11):2202-2211

Baba SM, Azad NA, Shah ZA, Pandith AA, Jan A, Aziz SA et al (2017) p15Ink4b loss of expression by promoter hypermethylation adds to leukemogenesis and confers a poor prognosis in acute promyelocytic leukemia patients. Cancer Res Treat 49(3):790-797

Bak RO, Gomez-Ospina N, Porteus MH (2018) Gene editing on center stage. Trends Genet 34(8):600-611

Baker A, Wyatt D, Bocchetta M, Li J, Filipovic A, Green A, Peiffer DS, Fuqua S, Miele L, Albain KS, Osipo C (2018) Notch-1-PTENERK1/2 signaling axis promotes HER2+ breast cancer cell proliferation and stem cell survival. Oncogene 37(33):4489-4504

Behan FM, Iorio F, Picco G, Gonçalves E, Beaver CM, Migliardi G, Santos R, Rao Y, Sassi F, Pinnelli M, Ansari R, Harper S, Jackson DA, McRae R, Pooley R, Wilkinson P, van der Meer D, 
Dow D, Buser-Doepner C, Bertotti A, Trusolino L, Stronach EA, Saez-Rodriguez J, Yusa K, Garnett MJ (2019) Prioritization of cancer therapeutic targets using CRISPR-Cas9 screens. Nature 568(7753):511-516

Benskey MJ, Manfredsson FP (2016) Lentivirus production and purification. Methods Mol Biol 1382:107-114

Boch J, Scholze H, Schornack S, Landgraf A, Hahn S, Kay S, Lahaye T, Nickstadt A, Bonas U (2009) Breaking the code of DNA binding specificity of TAL-type III effectors. Science 326(5959):1509-1512

Bogdanove AJ, Schornack S, Lahaye T (2010) TAL effectors: finding plant genes for disease and defense. Curr Opin Plant Biol 13(4):394-401

Brunetti PN, Ng P (2011) Helper-dependent adenoviral vectors for liver-directed gene therapy. Hum Mol Genet 20(R1):R7-R13

Burke JM, Lamm DL, Meng MV, Nemunaitis JJ, Stephenson JJ, Arseneau JC, Aimi J, Lerner S, Yeung AW, Kazarian T, Maslyar DJ, McKiernan JM (2012) A first in human phase 1 study of CG0070, a GM-CSF expressing oncolytic adenovirus, for the treatment of nonmuscle invasive bladder cancer. J Urol 188(6):2391-2397

Bushman FD (2020) Retroviral insertional mutagenesis in humans: evidence for four genetic mechanisms promoting expansion of cell clones. Mol Ther 28(2):352-356

Byeon Y, Lee JW, Choi WS, Won JE, Kim GH, Kim MG, Wi TI, Lee JM, Kang TH, Jung ID, Cho YJ, Ahn HJ, Shin BC, Lee YJ, Sood AK, Han HD, Park YM (2018) CD44-targeting PLGA nanoparticles incorporating paclitaxel and FAK siRNA overcome chemoresistance in epithelial ovarian cancer. Cancer Res 78(21):6247-6256

Capasso C, Garofalo M, Hirvinen M, Cerullo V (2014) The evolution of adenoviral vectors through genetic and chemical surface modifications. Viruses 6(2):832-855

Carninci P, Hayashizaki Y (2007) Noncoding RNA transcription beyond annotated genes. Curr Opin Genet Dev 17(2):139-144

Chang JC, Zhang L, Drilon AE, Chi P, Alaggio R, Borsu L, Benayed R, Travis WD, Ladanyi M, Antonescu CR (2019) Expanding the molecular characterization of thoracic inflammatory myofibroblastic tumors beyond ALK gene rearrangements. J Thorac Oncol 14(5):825-834

Chen RF, Lee CY (2014) Adenoviruses types, cell receptors and local innate cytokines in adenovirus infection. Int Rev Immunol 33(1):45-53

Chen C, Fenk LA, de Bono M (2013) Efficient genome editing in Caenorhabditis elegans by CRISPR-targeted homologous recombination. Nucleic Acids Res. https://doi.org/10.1093/nar/gkt805

Chen SH, Sun JM, Chen BM, Lin SC, Chang HF, Collins S, Chang D, Wu SF, Lu YC, Wang W, Chen TC, Kasahara N, Wang HE, Tai CK (2020) Efficient prodrug activator gene therapy by retroviral replicating vectors prolongs survival in an immune-competent intracerebral glioma model. Int J Mol Sci 21(4):1433

Chien PY, Wang J, Carbonaro D, Lei S, Miller B, Sheikh S, Ali SM, Ahmad MU, Ahmad I (2005) Novel cationic cardiolipin analogue-based liposome for efficient DNA and small interfering RNA delivery in vitro and in vivo. Cancer Gene Ther 12(3):321-328

Chiou GY, Cherng JY, Hsu HS, Wang ML, Tsai CM, Lu KH, Chien Y, Hung SC, Chen YW, Wong CI, Tseng LM, Huang PI, Yu CC, Hsu WH, Chiou SH (2012) Cationic polyurethanes-short branch PEI-mediated delivery of Mir145 inhibited epithelial-mesenchymal transdifferentiation and cancer stem-like properties and in lung adenocarcinoma. J Control Release 159(2):240-250

Couvreur P, Vauthier C (2006) Nanotechnology: intelligent design to treat complex disease. Pharm Res 23(7):1417-1450

Cui F, Hao ZX, Li J, Zhang YL, Li XK, He JX (2020) SOX2 mediates cisplatin resistance in small-cell lung cancer with downregulated expression of hsa-miR-340-5p. Mol Genet Genomic Med. https ://doi.org/10.1002/mgg3.1195

Dandan W, Jianliang C, Haiyan H, Hang M, Xuedong L (2019) Long noncoding RNA MIR31HG is activated by SP1 and promotes cell migration and invasion by sponging miR-214 in NSCLC. Gene 692:223-230

Derissen EJ, Beijnen JH, Schellens JH (2013) Concise drug review: azacitidine and decitabine. Oncologist 18(5):619-624

Derrien T, Johnson R, Bussotti G, Tanzer A, Djebali S, Tilgner H, Guernec G, Martin D, Merkel A, Knowles DG, Lagarde J, Veeravalli L, Ruan X, Ruan Y, Lassmann T, Carninci P, Brown JB, Lipovich L, Gonzalez JM, Thomas M, Davis CA, Shiekhattar R, Gingeras TR, Hubbard TJ, Notredame C, Harrow J, Guigó R (2012) The GENCODE v7 catalog of human long noncoding RNAs: analysis of their gene structure, evolution, and expression. Genome Res 22(9):1775-1789

Dull T, Zufferey R, Kelly M et al (1998) A third-generation lentivirus vector with a conditional packaging system. J Virol 72(11):8463-8471

Dunbar CE, High KA, Joung JK, Kohn DB, Ozawa K, Sadelain M (2018) Gene therapy comes of age. Science 359(6372):14672

Duncan R (2003) The dawning era of polymer therapeutics. Nat Rev Drug Discov 2(5):347-360

Elsner C, Bohne J (2017) The retroviral vector family: something for everyone. Virus Genes 53(5):714-722

ENCODE Project Consortium (2012) An integrated encyclopedia of DNA elements in the human genome. Nature 489(7414):57-74

Ferguson C, McKay M, Harris RA, Homanics GE (2013) Toll-like receptor $4(\mathrm{Tlr} 4)$ knockout rats produced by transcriptional activator-like effector nuclease (TALEN)-mediated gene inactivation. Alcohol 47(8):595-599

Fire A, Xu S, Montgomery MK, Kostas SA, Driver SE, Mello CC (1998) Potent and specific genetic interference by double-stranded RNA in Caenorhabditis elegans. Nature 391(6669):806-811

Flippot R, Beinse G, Boilève A, Vibert J, Malouf GG (2019) Long non-coding RNAs in genitourinary malignancies: a whole new world. Nat Rev Urol 16(8):484-504

Freytag SO, Stricker H, Lu M, Elshaikh M, Aref I, Pradhan D, Levin K, Kim JH, Peabody J, Siddiqui F, Barton K, Pegg J, Zhang Y, Cheng J, Oja-Tebbe N, Bourgeois R, Gupta N, Lane Z, Rodriguez R, DeWeese T, Movsas B (2014) Prospective randomized phase 2 trial of intensity modulated radiation therapy with or without oncolytic adenovirus-mediated cytotoxic gene therapy in intermediate-risk prostate cancer. Int J Radiat Oncol Biol Phys 89(2):268-276

Gaj T, Gersbach CA, Barbas CF 3rd (2013) ZFN, TALEN, and CRISPR/Cas-based methods for genome engineering. Trends Biotechnol 31(7):397-405

Galm O, Herman JG, Baylin SB (2006) The fundamental role of epigenetics in hematopoietic malignancies. Blood Rev 20(1):1-13

Gaucheron J, Boulanger C, Santaella C, Sbirrazzuoli N, Boussif O, Vierling P (2001) In vitro cationic lipid-mediated gene delivery with fluorinated glycerophosphoethanolamine helper lipids. Bioconjug Chem 12(6):949-963

Gaucheron J, Santaella C, Vierling P (2002) Transfection with fluorinated lipoplexes based on fluorinated analogues of DOTMA. DMRIE and DPPES Biochim Biophys Acta 1564(2):349-358

Golan T, Khvalevsky EZ, Hubert A, Gabai RM, Hen N, Segal A, Domb A, Harari G, David EB, Raskin S, Goldes Y, Goldin E, Eliakim R, Lahav M, Kopleman Y, Dancour A, Shemi A, Galun E (2015) RNAi therapy targeting KRAS in combination with chemotherapy for locally advanced pancreatic cancer patients. Oncotarget 6(27):24560-24570 
Gratz SJ, Wildonger J, Harrison MM, O'Connor-Giles KM (2013) CRISPR/Cas9-mediated genome engineering and the promise of designer flies on demand. Fly (Austin) 7(4):249-255

Griffiths-Jones S (2007) Annotating noncoding RNA genes. Annu Rev Genomics Hum Genet 8:279-298

Gros C, Fahy J, Halby L, Dufau I, Erdmann A, Gregoire JM, Ausseil F, Vispé S, Arimondo PB (2012) DNA methylation inhibitors in cancer: recent and future approaches. Biochimie 94(11):2280-2296

Grzeskowiak CL, Kundu ST, Mo X, Ivanov AA, Zagorodna O, Lu H, Chapple RH, Tsang YH, Moreno D, Mosqueda M, Eterovic K, Fradette JJ, Ahmad S, Chen F, Chong Z, Chen K, Creighton CJ, Fu H, Mills GB, Gibbons DL, Scott KL (2018) In vivo screening identifies GATAD2B as a metastasis driver in KRASdriven lung cancer. Nat Commun 9(1):2732

Hazekawa M, Nishinakagawa T, Kawakubo-Yasukochi T, Nakashima M (2019) Glypican-3 gene silencing for ovarian cancer using siRNA-PLGA hybrid micelles in a murine peritoneal dissemination model. J Pharmacol Sci 139(3):231-239

Hemminki O, Parviainen S, Juhila J, Turkki R, Linder N, Lundin J, Kankainen M, Ristimäki A, Koski A, Liikanen I, Oksanen M, Nettelbeck DM, Kairemo K, Partanen K, Joensuu T, Kanerva A, Hemminki A (2015) Immunological data from cancer patients treated with Ad5/3-E2F- $\Delta 24$-GMCSF suggests utility for tumor immunotherapy. Oncotarget 6(6):4467-4481

Hendrickx R, Stichling N, Koelen J, Kuryk L, Lipiec A, Greber UF (2014) Innate immunity to adenovirus. Hum Gene Ther 25(4):265-284

Hiwasa K, Nagaya H, Terao S, Acharya B, Hamada K, Mizuguchi H, Gotoh A (2012) Improved gene transfer into bladder cancer cells using adenovirus vector containing RGD motif. Anticancer Res 32(8):3137-3140

Hollenbach PW, Nguyen AN, Brady H, Williams M, Ning Y, Richard N, Krushel L, Aukerman SL, Heise C, MacBeth KJ (2010) A comparison of azacitidine and decitabine activities in acute myeloid leukemia cell lines. PLoS ONE 5(2):e9001

Howell PM, Liu Z, Khong HT (2010) Demethylating agents in the treatment of cancer. Pharmaceuticals (Basel) 3(7):2022-2044

Hung T, Chang HY (2010) Long noncoding RNA in genome regulation: prospects and mechanisms. RNA Biol 7(5):582-585

Iizuka K, Jin C, Eshima K, Hong MH, Eshima K, Fukushima M (2018) Anticancer activity of the intraperitoneal-delivered DFP-10825, the cationic liposome-conjugated RNAi molecule targeting thymidylate synthase, on peritoneal disseminated ovarian cancer xenograft model. Drug Des Devel Ther 12:673-683

Janjigian YY, Tang LH, Coit DG, Kelsen DP, Francone TD, Weiser MR, Jhanwar SC, Shah MA (2011) MET expression and amplification in patients with localized gastric cancer. Cancer Epidemiol Biomarkers Prev 20(5):1021-1027

Ji L, Fang B, Yen N, Fong K, Minna JD, Roth JA (1999) Induction of apoptosis and inhibition of tumorigenicity and tumor growth by adenovirus vector-mediated fragile histidine triad (FHIT) gene overexpression. Cancer Res 59(14):3333-3339

Jones MR, Williamson LM, Topham JT, Lee MKC, Goytain A, Ho J, Denroche RE, Jang GH, Pleasance E, Shen YQ, Karasinska J, McGhie JP, Gill S, Lim HJ, Moore MJ, Wong HL, Ng T, Yip S, Zhang W, Sadeghi S, Reisle C, Mungall AJ, Mungall KL, Moore RA, Ma T, Knox JJ, Gallinger S, Laskin J, Marra MA, Schaeffer DF, Jones SJM, Renouf DJ (2019) NRG1 gene fusions are recurrent, clinically actionable gene rearrangements in KRAS wild-type pancreatic ductal adenocarcinoma. Clin Cancer Res 25(15):4674-4681

Joung JK, Sander JD (2013) TALENs: a widely applicable technology for targeted genome editing. Nat Rev Mol Cell Biol 14(1):49-55

Jung TY, An Y, Park KH, Lee MH, Oh BH, Woo E (2015) Crystal structure of the Csm1 subunit of the Csm complex and its single-stranded DNA-specific nuclease activity. Structure 23(4):782-790

Kang JH, Tachibana Y, Kamata W, Mahara A, Harada-Shiba M, Yamaoka T (2010) Liver-targeted siRNA delivery by polyethylenimine (PEI)-pullulan carrier. Bioorg Med Chem 18(11):3946-3950

Karlsson J, Vaughan HJ, Green JJ (2018) Biodegradable polymeric nanoparticles for therapeutic cancer treatments. Annu Rev Chem Biomol Eng 9:105-127

Kenneth L (2018) Viral vectors in gene therapy. Diseases 6(2):42

Kim KH, Dmitriev IP, Saddekni S, Kashentseva EA, Harris RD, Aurigemma R, Bae S, Singh KP, Siegal GP, Curiel DT, Alvarez RD (2013) A phase I clinical trial of Ad5/3- $\Delta 24$, a novel serotype-chimeric, infectivity-enhanced, conditionally-replicative adenovirus (CRAd), in patients with recurrent ovarian cancer. Gynecol Oncol 130(3):518-524

Kim BK, Hwang GB, Seu YB, Choi JS, Jin KS, Doh KO (2015) DOTAP/DOPE ratio and cell type determine transfection efficiency with DOTAP-liposomes. Biochim Biophys Acta 1848:1996-2001

Kino T, Hurt DE, Ichijo T, Nader N, Chrousos GP (2010) Noncoding RNA gas5 is a growth arrest- and starvation-associated repressor of the glucocorticoid receptor. Sci Signal 3(107):ra8

Krishnamachary K, Glunde K, Wildes F, Mori N, Raman V, Bhujwalla Z (2007) Molecular imaging of lentiviral-mediated choline kinase gene silencing therapy in breast cancer model. Can Res 67(9):5469

Kurita K, Maeda M, Mansour MA, Kokuryo T, Uehara K, Yokoyama Y, Nagino M, Hamaguchi M, Senga T (2016) TRIP13 is expressed in colorectal cancer and promotes cancer cell invasion. Oncol Lett 12(6):5240-5246

Lander ES, Linton LM, Birren B, Nusbaum C, Zody MC, Baldwin J, Devon K, Dewar K, Doyle M, FitzHugh W, Funke R, Gage D, Harris K, Heaford A, Howland J, Kann L, Lehoczky J, LeVine R, McEwan P, McKernan K, Meldrim J, Mesirov JP, Miranda C, Morris W, Naylor J, Raymond C, Rosetti M, Santos R, Sheridan A, Sougnez C (2001) Initial sequencing and analysis of the human genome. Nature 409(6822):860-921

Ledwith BJ, Joslyn DJ, Troilo P, Leander KR, Clair JH, Soper KA, Manam S, Prahalada S, van Zwieten MJ, Nichols WW (1995) Induction of minisatellite DNA rearrangements by genotoxic carcinogens in mouse liver tumors. Carcinogenesis 16(5):1167-1172

Lee S, Cobrinik D (2020) Improved third-generation lentiviral packaging with $\mathrm{pLKO} .1 \mathrm{C}$ vectors. Biotechniques. https://doi. org/10.2144/btn-2019-0155

Lee HY, Mohammed KA, Kaye F, Sharma P, Moudgil BM, Clapp WL, Nasreen N (2013) Targeted delivery of let-7a microRNA encapsulated ephrin-A1 conjugated liposomal nanoparticles inhibit tumor growth in lung cancer. Int J Nanomed 8:4481-4494

Li J, Chen YC, Tseng YC, Mozumdar S, Huang L (2010) Biodegradable calcium phosphate nanoparticle with lipid coating for systemic siRNA delivery. J Control Release 142:416-421

Li J, Li S, Xia S, Feng J, Zhang X, Hao Y, Chen L, Zhang X (2015) Enhanced transfection efficiency and targeted delivery of selfassembling h-R3-dendriplexes in EGFR-overexpressing tumor cells. Oncotarget 6(28):26177-26191

Li J, Liang H, Liu J, Wang Z (2018) Poly (amidoamine) (PAMAM) dendrimer mediated delivery of drug and pDNA/siRNA for cancer therapy. Int J Pharm 546(1-2):215-225

Lim DG, Rajasekaran N, Lee D, Kim NA, Jung HS, Hong S, Shin YK, Kang E, Jeong SH (2017) Polyamidoamine-decorated nanodiamonds as a hybrid gene delivery vector and siRNA structural characterization at the charged interfaces. ACS Appl Mater Interfaces 9(37):31543-31556

Lima WF, Prakash TP, Murray HM et al (2012) Single-stranded siRNAs activate RNAi in animals. Cell 150(5):883-894 
Liu G, Choi KY, Bhirde A, Swierczewska M, Yin J, Lee SW, Park JH, Hong JI, Xie J, Niu G, Kiesewetter DO, Lee S, Chen X (2012) Sticky nanoparticles: a platform for siRNA delivery by a bis(zinc(II) dipicolylamine)-functionalized, self-assembled nanoconjugate. Angew Chem Int Ed Engl 51(2):445-449

Liu X, Wang M, Qin Y, Shi X, Cong P, Chen Y, He Z (2018) Targeted integration in human cells through single crossover mediated by ZFN or CRISPR/Cas9. BMC Biotechnol 18(1):66

Makarova KS, Aravind L, Wolf YI, Koonin EV (2011) Unification of Cas protein families and a simple scenario for the origin and evolution of CRISPR-Cas systems. Biol Direct 6:38

Makarova KS, Haft DH, Barrangou R, Brouns SJ, Charpentier E, Horvath P, Moineau S, Mojica FJ, Wolf YI, Yakunin AF, van der Oost J, Koonin EV (2011) Evolution and classification of the CRISPR-Cas systems. Nat Rev Microbiol 9(6):467-477

Makarova KS, Wolf YI, Alkhnbashi OS, Costa F, Shah SA, Saunders SJ, Barrangou R, Brouns SJ, Charpentier E, Haft DH, Horvath P, Moineau S, Mojica FJ, Terns RM, Terns MP, White MF, Yakunin AF, Garrett RA, van der Oost J, Backofen R, Koonin EV (2015) An updated evolutionary classification of CRISPR-Cas systems. Nat Rev Microbiol 13(11):722-736

Mandal PK, Ferreira LM, Collins R, Meissner TB, Boutwell CL, Friesen M, Vrbanac V, Garrison BS, Stortchevoi A, Bryder D, Musunuru K, Brand H, Tager AM, Allen TM, Talkowski ME, Rossi DJ, Cowan CA (2014) Efficient ablation of genes in human hematopoietic stem and effector cells using CRISPR/Cas9. Cell Stem Cell 15(5):643-652

Matsumura Y, Maeda H (1986) A new concept for macromolecular therapeutics in cancer chemotherapy: mechanism of tumoritropic accumulation of proteins and the antitumor agent smancs. Cancer Res 46(12 Pt 1):6387-6392

Mercer TR, Dinger ME, Mattick JS (2009) Long non-coding RNAs: insights into functions. Nat Rev Genet 10(3):155-159

Milone MC, O'Doherty U (2018) Clinical use of lentiviral vectors. Leukemia 32(7):1529-1541

Mohanraj VJ, Chen Y (2007) Nanoparticles: a review. Trop J Pharm Res 5(1):561-573

Montesinos P, González JD, González J, Rayón C, de Lisa E, Amigo ML, Ossenkoppele GJ, Peñarrubia MJ, Pérez EM, Bergua J, Debén G, Sayas MJ, de la Serna J, Ribera JM, Bueno J, Milone G, Rivas C, Brunet S, Löwenberg B, Sanz M (2010) Therapyrelated myeloid neoplasms in patients with acute promyelocytic leukemia treated with all-trans-retinoic Acid and anthracyclinebased chemotherapy. J Clin Oncol 28(24):3872-3879

Moore LD, Le T, Fan G (2013) DNA methylation and its basic function. Neuropsychopharmacology 38(1):23-38

Morita S, Kojima T, Kitamura T (2000) Plat-E: an efficient and stable system for transient packaging of retroviruses. Gene Ther 7(12):1063-1066

Moscou MJ, Bogdanove AJ (2009) A simple cipher governs DNA recognition by TAL effectors. Science 326(5959): 1501

Müller S, Bexte T, Gebel V, Kalensee F, Stolzenberg E, Hartmann J, Koehl U, Schambach A, Wels WS, Modlich U, Ullrich E (2020) High cytotoxic efficiency of lentivirally and alpharetrovirally engineered CD19-specific chimeric antigen receptor natural killer cells against acute lymphoblastic leukemia. Front Immunol 10:3123

Neuberg P, Kichler A (2014) Recent developments in nucleic acid delivery with polyethylenimines. Adv Genet 88:263-288

Newman AM, Bratman SV, Stehr H, Lee LJ, Liu CL, Diehn M, Alizadeh AA (2014) FACTERA: a practical method for the discovery of genomic rearrangements at breakpoint resolution. Bioinformatics 30(23):3390-3393
Nie C, Zhu C, Feng L, Lv F, Liu L, Wang S (2013) Synthesis of a new conjugated polymer for DNA alkylation and gene regulation. ACS Appl Mater Interfaces 5(11):4549-4554

Nobles CL, Sherrill-Mix S, Everett JK, Reddy S, Fraietta JA, Porter DL, Frey N, Gill SI, Grupp SA, Maude SL, Siegel DL, Levine BL, June CH, Lacey SF, Melenhorst JJ, Bushman FD (2020) CD19-targeting CAR T cell immunotherapy outcomes correlate with genomic modification by vector integration. J Clin Invest 130(2):673-685

Nwanegbo E, Vardas E, Gao W, Whittle H, Sun H, Rowe D, Robbins PD, Gambotto A (2004) Prevalence of neutralizing antibodies to adenoviral serotypes 5 and 35 in the adult populations of The Gambia, South Africa, and the United States. Clin Diagn Lab Immunol 11(2):351-357

Owens DE 3rd, Peppas NA (2006) Opsonization, biodistribution, and pharmacokinetics of polymeric nanoparticles. Int J Pharm 307(1):93-102

Ozpolat B, Sood AK, Lopez-Berestein G (2014) Liposomal siRNA nanocarriers for cancer therapy. Adv Drug Deliv Rev 66:110-116

Pack DW, Hoffman AS, Pun S, Stayton PS (2005) Design and development of polymers for gene delivery. Nat Rev Drug Discov 4(7):581-593

Pandey RR, Mondal T, Mohammad F, Enroth S, Redrup L, Komorowski J, Nagano T, Mancini-Dinardo D, Kanduri C (2008) Kcnq1 ot1 antisense noncoding RNA mediates lineage-specific transcriptional silencing through chromatin-level regulation. Mol Cell 32(2):232-246

Park SY, Kwon HJ, Lee HE, Ryu HS, Kim SW, Kim JH, Kim IA, Jung N, Cho NY, Kang GH (2011) Promoter CpG island hypermethylation during breast cancer progression. Virchows Arch 458(1):73-84

Park JH, Seo JH, Jeon HY, Seo SM, Lee HK, Park JI, Kim JY, Choi YK (2020) Lentivirus-mediated VEGF knockdown suppresses gastric cancer cell proliferation and tumor growth in vitro and in vivo. Onco Targets Ther 13:1331-1341

Pauli A, Rinn JL, Schier AF (2011) Non-coding RNAs as regulators of embryogenesis. Nat Rev Genet 12(2):136-149

Pesonen S, Diaconu I, Cerullo V, Escutenaire S, Raki M, Kangasniemi L, Nokisalmi P, Dotti G, Guse K, Laasonen L, Partanen K, Karli E, Haavisto E, Oksanen M, Karioja-Kallio A, Hannuksela P, Holm SL, Kauppinen S, Joensuu T, Kanerva A, Hemminki A (2012) Integrin targeted oncolytic adenoviruses Ad5-D24-RGD and Ad5-RGD-D24-GMCSF for treatment of patients with advanced chemotherapy refractory solid tumors. Int J Cancer 130(8):1937-1947

Plath K, Mlynarczyk-Evans S, Nusinow DA, Panning B (2002) Xist RNA and the mechanism of $\mathrm{X}$ chromosome inactivation. Annu Rev Genet 36:233-278

Prensner JR, Chen W, Han S, Iyer MK, Cao Q, Kothari V, Evans JR, Knudsen KE, Paulsen MT, Ljungman M, Lawrence TS, Chinnaiyan AM, Feng FY (2014) The long non-coding RNA PCAT-1 promotes prostate cancer cell proliferation through $\mathrm{cMyc}$. Neoplasia 16(11):900-908

Pujade LE, Wagner U, Aavall-Lundqvist E, Gebski V, Heywood M, Vasey PA, Volgger B, Vergote I, Pignata S, Ferrero A, Sehouli J, Lortholary A, Kristensen G, Jackisch C, Joly F, Brown C, Le Fur N, du Bois A (2010) Pegylated liposomal Doxorubicin and Carboplatin compared with Paclitaxel and Carboplatin for patients with platinum-sensitive ovarian cancer in late relapse. $\mathbf{J}$ Clin Oncol 28(20):3323-3329

Qi Z, Mi R (2016) Inhibition of human telomerase reverse transcriptase in vivo and in vitro for retroviral vector-based antisense oligonucleotide therapy in ovarian cancer. Cancer Gene Ther 23(1):36-42 
Quintarelli C, Sivori S, Caruso S, Carlomagno S, Falco M, Boffa I, Orlando D, Guercio M, Abbaszadeh Z, Sinibaldi M, Di Cecca S, Camera A, Cembrola B, Pitisci A, Andreani M, Vinti L, Gattari S, Del Bufalo F, Algeri M, Li Pira G, Moseley A, De Angelis B, Moretta L, Locatelli F (2019) Efficacy of third-party chimeric antigen receptor modified peripheral blood natural killer cells for adoptive cell therapy of B-cell precursor acute lymphoblastic leukemia. Leukemia 34(4):1102-1115

Raper SE, Chirmule N, Lee FS, Wivel NA, Bagg A, Gao GP, Wilson JM, Batshaw ML (2003) Fatal systemic inflammatory response syndrome in an ornithine transcarbamylase deficient patient following adenoviral gene transfer. Mol Genet Metab 80(1-2):148-158

Rath D, Amlinger L, Rath A, Lundgren M (2015) The CRISPR-Cas immune system: biology, mechanisms and applications. Biochimie 117:119-128

Richly H, Aloia L, Di Croce L (2011) Roles of the Polycomb group proteins in stem cells and cancer. Cell Death Dis 2(9):e204

Rinn JL, Chang HY (2012) Genome regulation by long noncoding RNAs. Annu Rev Biochem 81:145-166

Rinn JL, Kertesz M, Wang JK, Squazzo SL, Xu X, Brugmann SA, Goodnough LH, Helms JA, Farnham PJ, Segal E, Chang HY (2007) Functional demarcation of active and silent chromatin domains in human HOX loci by noncoding RNAs. Cell 129(7):1311-1323

Rush LJ, Plass C (2002) Alterations of DNA methylation in hematologic malignancies. Cancer Lett 185(1):1-12

Sakuma T, Barry MA, Ikeda Y (2012) Lentiviral vectors: basic to translational. Biochem J 443(3):603-618

Sant SB (2012) Nanoparticles: from theory to applications. Mater Manuf Processes 27(12):1-123

Schlom J, Moloney JB, Groupé V (1970) Immunological and pathological manifestations of murine sarcoma virus (Moloney) infections. Cancer Res 30(12):2955-2961

Schultheis B, Strumberg D, Santel A, Vank C, Gebhardt F, Keil O, Lange C, Giese K, Kaufmann J, Khan M, Drevs J (2014) Firstin-human phase I study of the liposomal RNA interference therapeutic Atu027 in patients with advanced solid tumors. J Clin Oncol 32(36):4141-4148

Seol H, Lee HJ, Choi Y, Lee HE, Kim YJ, Kim JH, Kang E, Kim SW, Park SY (2012) Intratumoral heterogeneity of HER2 gene amplification in breast cancer: its clinicopathological significance. Mod Pathol 25(7):938-948

Shalem O, Sanjana NE, Hartenian E, Shi X, Scott DA, Mikkelson T, Heckl D, Ebert BL, Root DE, Doench JG, Zhang F (2014) Genome-scale CRISPR-Cas9 knockout screening in human cells. Science 343(6166):84-87

Sharp PM, Shaw GM, Hahn BH (2005) Simian immunodeficiency virus infection of chimpanzees. J Virol 79(7):3891-3902

Shaw AT, Yeap BY, Solomon BJ, Riely GJ, Gainor J, Engelman JA, Shapiro GI, Costa DB, Ou SH, Butaney M, Salgia R, Maki RG, Varella-Garcia M, Doebele RC, Bang YJ, Kulig K, Selaru P, Tang Y, Wilner KD, Kwak EL, Clark JW, Iafrate AJ, Camidge DR (2011) Effect of crizotinib on overall survival in patients with advanced non-small-cell lung cancer harbouring ALK gene rearrangement: a retrospective analysis. Lancet Oncol 12(11):1004-1012

Shen H, Sun T, Ferrari M (2012) Nanovector delivery of siRNA for cancer therapy. Cancer Gene Ther 19(6):367-373

Silva AC, Peixoto C, Lucas T, Küppers C, Cruz PE, Alves PM, Kochanek S (2010) Adenovirus vector production and purification. Curr Gene Ther 10(6):437-455

Singhi AD, Cimino-Mathews A, Jenkins RB, Lan F, Fink SR, Nassar H, Vang R, Fetting JH, Hicks J, Sukumar S, De Marzo AM, Argani P (2012) MYC gene amplification is often acquired in lethal distant breast cancer metastases of unamplified primary tumors. Mod Pathol 25(3):378-387

Soppimath KS, Aminabhavi TM, Kulkarni AR, Rudzinski WE (2001) Biodegradable polymeric nanoparticles as drug delivery devices. J Control Release 70(1-2):1-20

Su J, Zhou Y, Pan Z, Shi L, Yang J, Liao A, Liao Q, Su Q (2017) Downregulation of LIMK1-ADF/cofilin by DADS inhibits the migration and invasion of colon cancer. Sci Rep 7:45624

Suurmeijer AJ, Dickson BC, Swanson D, Zhang L, Sung YS, Huang HY, Fletcher CD, Antonescu CR (2019) The histologic spectrum of soft tissue spindle cell tumors with NTRK3 gene rearrangements. Genes Chromosomes Cancer 58(11):739-746

Tamura R, Miyoshi H, Yoshida K, Okano H, Toda M (2019) Recent progress in the research of suicide gene therapy for malignant glioma. Neurosurg Rev. https://doi.org/10.1007/s10143-01901203-3

Tan W, Carlson D, Fahrenkrug S (2013) TALEN enabled efficient precision genome editing in pig and cattle. Transgenic Res 22(1):237-238

Thomas GP, Mathews MB (1980) DNA replication and the early to late transition in adenovirus infection. Cell 22(2 Pt 2):523-533

Tigre DM, Brandão CF, de Paula FL, Chinalia FA, Campos GS, Sardi SI (2017) Characterization of isolates of equine infectious anemia virus in Brazil. Arch Virol 162(3):873-877

Toietta G, Pastore L, Cerullo V, Finegold M, Beaudet AL, Lee B (2002) Generation of helper-dependent adenoviral vectors by homologous recombination. Mol Ther 5(2):204-210

Tripathi V, Ellis JD, Shen Z, Song DY, Pan Q, Watt AT, Freier SM, Bennett CF, Sharma A, Bubulya PA, Blencowe BJ, Prasanth SG, Prasanth KV (2010) The nuclear-retained noncoding RNA MALAT1 regulates alternative splicing by modulating SR splicing factor phosphorylation. Mol Cell 39(6):925-938

Tsai MC, Manor O, Wan Y, Mosammaparast N, Wang JK, Lan F, Shi Y, Segal E, Chang HY (2010) Long noncoding RNA as modular scaffold of histone modification complexes. Science 329(5992):689-693

Tsai MC, Spitale RC, Chang HY (2011) Long intergenic noncoding RNAs: new links in cancer progression. Cancer Res 71(1):3-7

U1 Ain Q, Chung JY, Kim YH (2015) Current and future delivery systems for engineered nucleases: ZFN, TALEN and RGEN. J Control Release 205:120-127

Venter JC, Adams MD, Myers EW, Li PW, Mural RJ, Sutton GG, Smith HO, Yandell M, Evans CA, Holt RA, Gocayne JD, Amanatides P, Ballew RM, Huson DH, Wortman JR, Zhang Q, Kodira CD, Zheng XH, Chen L, Skupski M, Subramanian G, Thomas PD, Zhang J, Gabor Miklos GL, Nelson C, Broder S, Clark AG, Nadeau J, McKusick VA, Zinder N (2001) The sequence of the human genome. Science 291(5507):1304-1351

Wang KC, Chang HY (2011) Molecular mechanisms of long noncoding RNAs. Mol Cell 43(6):904-914

Wang X, Jiang W, Kang J, Liu Q, Nie M (2015) Knockdown of RhoA expression alters ovarian cancer biological behavior in vitro and in nude mice. Oncol Rep 34(2):891-899

Wang Y, Gao F, Jiang X, Zhao X, Wang Y, Kuai Q, Nie G, He M, Pan Y, Shi W, Ren S, Yu Q (2019) Co-delivery of gemcitabine and Mcl-1 SiRNA via cationic liposome-based system enhances the efficacy of chemotherapy in pancreatic cancer. $\mathbf{J}$ Biomed Nanotechnol 15(5):966-978

Wu Y, Liang D, Wang Y, Bai M, Tang W, Bao S, Yan Z, Li D, Li J (2013) Correction of a genetic disease in mouse via use of CRISPR-Cas9. Cell Stem Cell 13(6):659-662

Xie W, Baylin SB, Easwaran H (2019) DNA methylation in senescence, aging and cancer. Oncoscience 6(1-2):291-293

Yang Y, Li J, Liu F, Huang L (2012) Systemic delivery of siRNA via LCP nanoparticle efficiently inhibits lung metastasis. Mol Ther 20(3):609-615 
Yang J, Yuan P, Wen D, Sheng Y, Zhu S, Yu Y, Gao X, Wei W (2013) ULtiMATE system for rapid assembly of customized TAL effectors. PLoS ONE 8(9):e75649

Yang G, Lu X, Yuan L (2014) LncRNA: a link between RNA and cancer. Biochim Biophys Acta 1839(11):1097-1109

Yu J, Xie T, Wang Z, Wang Z, Wang X, Zeng S, Kang Y, Hou T (2019) DNA methyltransferases: emerging targets for the discovery of inhibitors as potent anticancer drugs. Drug Discov Today 24(12):2323-2331

Zeng Q, Han J, Zhao D, Gong T, Zhang Z, Sun X (2012) Protection of adenovirus from neutralizing antibody by cationic PEG derivative ionically linked to adenovirus. Int J Nanomed 7:985-997

Zhang F, Wen Y, Guo X (2014) CRISPR/Cas9 for genome editing: progress, implications and challenges. Hum Mol Genet 23(R1):R40-R46

Zhang Y, Li Z, Zhang Y, Zhong Q, Chen Q, Zhang L (2015) Molecular mechanism of HEIH and HULC in the proliferation and invasion of hepatoma cells. Int J Clin Exp Med 8(8):12956-12962
Zhen S, Li X (2019) Liposomal delivery of CRISPR/Cas9. Cancer Gene Ther. https://doi.org/10.1038/s41417-019-0141-7

Zhi D, Bai Y, Yang J, Cui S, Zhao Y, Chen H, Zhang S (2018) A review on cationic lipids with different linkers for gene delivery. Adv Colloid Interface Sci 253:117-140

Zhu J, Fu H, Wu Y, Zheng X (2013) Function of lncRNAs and approaches to lncRNA-protein interactions. Sci China Life Sci 56(10):876-885

Zou X, Owusu M, Harris R, Jackson SP, Loizou JI, Nik-Zainal S (2018) Validating the concept of mutational signatures with isogenic cell models. Nat Commun 9(1):1744

Zu Y, Tong X, Wang Z, Liu D, Pan R, Li Z, Hu Y, Luo Z, Huang P, Wu Q, Zhu Z, Zhang B, Lin S (2013) TALEN-mediated precise genome modification by homologous recombination in zebrafish. Nat Methods 10(4):329-331

Publisher's Note Springer Nature remains neutral with regard to jurisdictional claims in published maps and institutional affiliations. 